\title{
IDENTIFYING AND VALUING GOODWILL AT DIVORCE
}

\author{
GRACE GANZ BLUMBERG*
}

TABLE OF CONTENTS

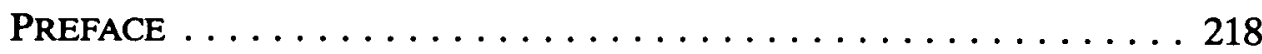

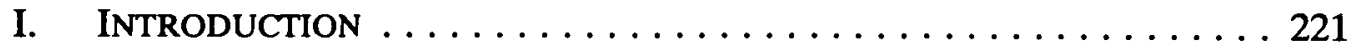

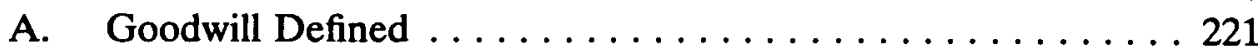

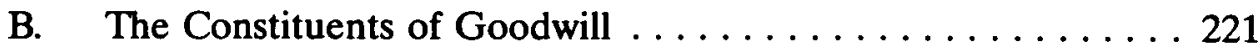

C. The Life of Goodwill: Its Duration and Vigor ........ 222

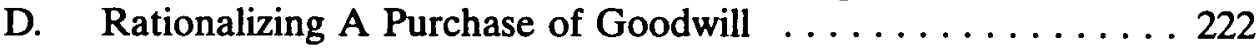

E. The Sale of Goodwill from the Seller's Perspective-Tax

Considerations ....................... 226

II. PROFESSIONAL AND COMMERCIAL GOODWILL AS AN ASSET AT

Divorce: What are We Trying to Measure? . . . . . . . . . 229

A. Exposition and Evaluation of the Position that Goodwill May

$\mathrm{Be}$ Measurable by Excess Earnings and Need Not Be

Marketable To Be Cognizable at Divorce ............ 231

B. Exposition and Evaluation of the Minority Position that Marital Property Recognition Should Be Limited to Marketable Goodwill ........................ 233

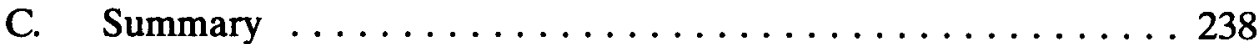

III. IsSUES IN MARKet VALUATION $\ldots \ldots \ldots \ldots \ldots \ldots \ldots \ldots \ldots 239$

A. Market Value as the Ultimate Measure, Whether Direct (Market Sales Price) or Hypothetical (Capitalization of Excess Earnings) .................... 239

B. For Divorce Valuation, Market Sales Prices Should Represent a Floor and Capitalization Rates Derived from Market Transactions Should Represent a Ceiling . . . . . . . . 240

C. When Market Sales and Capitalization Produce Widely Different Estimates of Value, the Experts Should Be Expected to Explain and Rationalize the Variation .......... 241

IV. THE Excess Earnings Measure of Traditional Professional

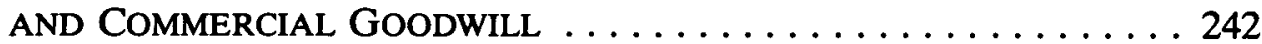

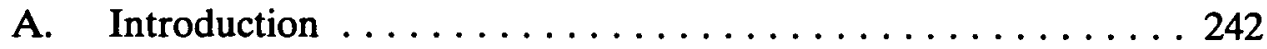

Copyright (c) 1993 by Law and Contemporary Problems

This article is adapted in part with permission from Chapter 25, VALuATION \& Distribution of MARITAL PROPERTY, copyright $\odot 1992$ by Matthew Bender \& Co., Inc. All rights reserved.

*Professor of Law, University of California, Los Angeles.

I thank my colleagues Michael Asimow and William Klein for their helpful comments on an early draft ot this article. 


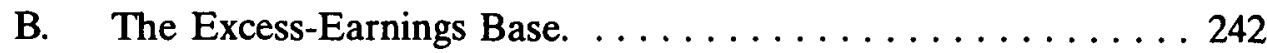

C. Capitalization Rates: A Contested Ground . . . . . . . . 246

D. Other Discount Factors: Depreciation and Taxation ..... 250

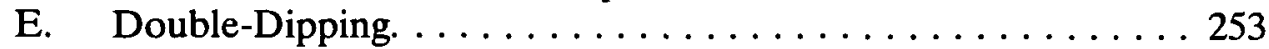

V. ISSUES INCIDENT TO THE TRANSFER OF GOODWILL $\ldots \ldots \ldots \ldots 262$

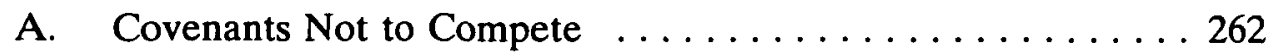

B. Promises to Continue in the Practice or Business . . . . . . 263

VI. EXPANDING THE CONCEPT OF PROFESSIONAL AND COMMERCIAL GOODWILL TO RELATED FORMS OF GOODWILL AND TO ENHANCED

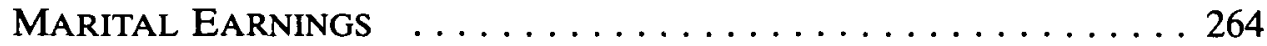

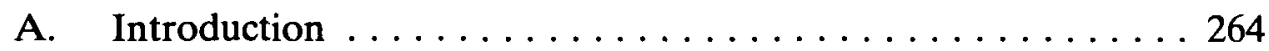

B. Various Meanings of "Excess Earnings" ... . . . . . . 264

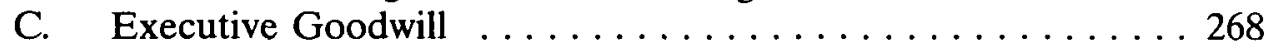

D. Entrepreneurial Employee Goodwill . . . . . . . . . . 268

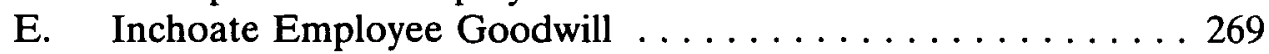

F. Celebrity Goodwill ..................... 269

G. Hitting the Wall: Current Earnings are Often, to Some

Extent, Enhanced by Prior Accomplishment . . . . . . . 271

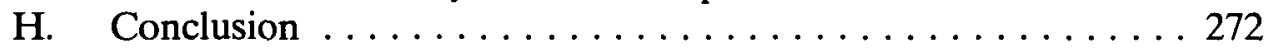

VII. CONCLUSION ......................... 272

\section{PREFACE}

Professional and business goodwill is a troubling and difficult area of divorce law. It sits poised between two discrete and generally distinguishable branches of divorce doctrine: property distribution and support. Although an intangible asset, goodwill may be identified and reified by market-sales valuation and excess-earnings capitalization, which suggests that it should be treated as a distributable asset at divorce. Yet the value of goodwill at divorce is, in most cases, realized only in the practitioner's ${ }^{1}$ stream of future postdivorce earnings, ${ }^{2}$ the stream of income to which we generally look for spousal and child support. It is not simply that goodwill resists easy categorization. Extended to its logical limits, marital property law's inclusion of goodwill and goodwill derivatives would subsume much of the ground now consigned to spousal support, and, importantly, would recast postdivorce wealth transfer in terms of property entitlements rather than more tenuous support claims.

Goodwill is thus a highly charged and contested area, one in which ostensibly technical debate may mask fundamental differences about the desirability and optimal extent of family wealth distribution at divorce and therefore one in

1. I use the term "practitioner" to refer to both the business and professional manager-owner.

2. This is true even for largely marketable, or transferable, goodwill. The practitioner is likely to retain his business or practice, realizing the value of marital goodwill in his stream of future earnings. In most cases, retention is economically preferable to sale. See infra text accompanying notes 46-47. 
which technical obfuscation and error are as likely to be instrumental as accidental. From this perspective, one might conclude that no examination of goodwill should be undertaken before establishing a position or consensus on optimal wealth distribution at divorce. On the other hand, an exploration of goodwill itself casts some light on the subject of divorce-related wealth distribution because it causes us to evaluate substantive claims that have-not spouses make and might make. More immediately, courts and litigants deal daily with a number of goodwill issues that have not been closely or critically examined in the legal literature. This article attempts to be both definitive and exploratory, definitive in attempting to lay to rest what I perceive as some basic but pervasive technical error, and exploratory in examining the puzzles that goodwill currently presents and the directions in which legal treatment of goodwill might proceed.

I come to this subject as a California law professor who regularly teaches marital property law and has edited a state marital property casebook that offers extended coverage of employment-related property claims. I am an earlymarried, never-divorced, middle-aged wife and mother, and I possess professional goodwill. I consider my professional status the result of hard work, intelligence, good luck, spousal support, and, most importantly, social deviance. Growing up as a woman, I was peculiarly and unaccountably unresponsive, even resistant, to social cues and pressures. ${ }^{3}$

Three years ago I agreed to be a reporter for a pilot project of the Family Law Committee of the California Judicial Council. ${ }^{4}$ The Committee wished to tackle a difficult area and possibly, through its rule-making power, effect some constructive change in California family law. The Committee chose goodwill and organized day-long colloquia in five California cities. ${ }^{5}$ Local family law judges invited attorneys and accountants to present and respond to brief papers.

California has, doctrinally, been a leading exponent of expansive measurement of goodwill, recognizing nontransferable as well as transferable goodwill and hence allowing capitalization of excess earnings as well as market-sales

3. Behaviors that are increasingly seen as acceptable in either sex by middle-class American parents were perceived as deeply problematic in a girl by my middle-class family and community in the forties, fifties, and early sixties, sufficiently problematic to require psychiatric intervention. Such behaviors included intellectual curiosity, argumentativeness, iconoclasm, love of math, bookishness, athleticism, physical adventurousness and risk-taking, and dislike of physically restrictive clothing. The concern was less sexual orientation than gender identity: How would I ever make a successful adjustment to wifehood and motherhood? My parents, school counselors, and mental health professionals agreed: I needed psychiatric help in order to develop a "feminine identity." Fortunately for me, an unwilling patient is untreatable, and the psychiatric project was abandoned.

4. The Judicial Council is a constitutional agency (CAL. CONST. art. VI, § 6) directed to survey judicial business and make recommendations to the courts, the Governor, and the Legislature, to adopt rules, not inconsistent with statute, for court administration, practice, and procedure, and perform other functions prescribed by statute. Its role under the Family Law Act is substantial. Civil Code section 4001 provides: "Notwithstanding any other provision of law, the Judicial Council may provide by rule for the practice and procedure in proceedings under [the Family Law Act]."

5. In the fall of 1990, the five colloquia were held in San Diego, San Francisco, Sacramento, Fresno, and Los Angeles. 
measurement. Nevertheless, a substantial minority of participants expressed remarkable resistance to the generous appellate law on the books. Relatively few attorneys or accountants, although rather more trial court judges, totally rejected capitalization measures. Instead, many embraced arguably incorrect valuation practices that tend to down-value goodwill, even practices specifically disapproved by state appellate law. ${ }^{6}$

The sex divide was dramatic. Every one of the few ${ }^{7}$ women panelists promoted generous definitions of goodwill and criticized unwarranted and unlawful limiting valuation practices. A fair number of men, particularly accountants, agreed with them. On the other side, only male participants opposed capitalization and sought to limit valuation improperly. Such men were prone to detect "feminist bias" in women participants, including this writer, who did not agree with them. Yet there was only one woman panelist who represented a feminist organization; all the rest could best be described as "successful professional women."

I was struck by this charge of "feminist bias" because the personal bias of any professional would be to oppose goodwill recognition. All colloquia participants, men and women, were "economically male." The "bias," if any, surely must have been "masculinist" although we are unlikely to think in such terms, male generally being equated with normal and unbiased. It is true, of course, that the women participants may not have been thinking only of themselves. They were probably thinking empathetically about the majority of women who are not economically male. Yet the posture of women professionals, positioned between professional self-interest and concern for women who are less economically advantaged, arguably makes them most free of gender "bias." In contrast, the male professionals who strongly resisted generous measures of goodwill seemed doubly biased in the sense that self-interest reinforced empathetic concern for other men, who are professionals like themselves. A few male panelists were introspective about the self-interest of their position, but participants more frequently expressed it unselfconsciously in angry, even hysterical, ${ }^{8}$ rhetoric. Yet

6. See, e.g., infra text accompanying notes 105-15.

7. Sexual imbalance was noteworthy: Fewer than $20 \%$ of the panelists were women, and there were no participating female judges.

8. Attorneys opposing marital property recognition of professional goodwill often asserted that professional practices are extremely fragile, despite common experience to the contrary. To make their point, they invoked such possibilities as a catastrophic and notorious malpractice award, a practitioner's decline into alcoholism or drug addiction, and premature senility or death. I initially understood this as an expression of self-interested and self-protective anxiety about the stability of their own marriages. Alternatively or additionally, it may also reflect a high level of anxiety about the economic success that they have achieved as professionals. Writing of the professional middle class, Barbara Ehrenreich observed:

Its only "capital" is knowledge and skill, or at least the credentials imputing skill and knowledge. And unlike [physical] capital, these cannot be hoarded against hard times, preserved beyond the lifetime of an individual, or, of course, bequeathed .... In this class, no one escapes the requirements of self-discipline and self-directed labor ....

If this is an elite, then, it is an insecure and deeply anxious one. It is afraid, like any class below the most securely wealthy, of misfortunes that might lead to a downward slide. But in the middle class, there is another anxiety: a fear of inner weakness, of growing soft, of 
other men, particularly forensic accountants and attorneys, were able to transcend self-interest and sympathetically evaluate the goodwill claims of the have-not spouse. I report this experience to bring to the surface issues of selfinterest and bias and to show that even in California, with decades of experience, goodwill remains a volatile and much-contested battleground in divorce law.

Finally, throughout the text I have assumed that the business or professional spouse is the husband. I do this for clarity and consistency, linguistic simplicity, because it is far more likely than not, and because the alternative, linguistic egalitarianism, may cause us to lose touch with social reality.

\section{I}

\section{INTRODUCTION}

The first portion of this article sets out a generally accepted economic and accounting definition of goodwill, and then schematically reconstructs a market purchase and sale of goodwill in order to identify recurrent concepts and questions that arise in identification and measurement of goodwill. This serves as a prelude to discussion of divorce-related issues so that readers may share a common understanding of certain underlying assumptions and overarching principles before the article addresses issues that may be particular to property distribution at divorce.

\section{A. Goodwill Defined}

Goodwill is widely understood today as a constellation of inseparable intangible assets that inhere in a business or practice and enable it to realize supernormal earnings. The earnings are supernormal in the sense that they exceed the sum of the market value of the manager's labor and a reasonable return on all tangible assets and individually quantifiable intangible assets. The supernormal earnings are usually characterized as excess earnings; their existence is both an indicator of goodwill and an important factor in measurement of its value.

\section{B. The Constituents of Goodwill}

Because goodwill is a residuum of assets we are otherwise unable to quantify individually, ${ }^{9}$ any listing of goodwill constituents is necessarily illustrative rather than exhaustive. In addition to reputation and continuing patronage, goodwill may include, inter alia, strategic location, effective advertising, the value of a skilled, trained, efficient work force, assemblage of property, plant, and

failing to strive, of losing discipline and will. Even the affluence that is so often the goal of all this striving becomes a threat, for it holds out the possibility of hedonism and selfindulgence. Whether the [professional] middle class looks down toward the realm of less, or up toward the realm of more, there is the fear, always, of falling.

Barbara Ehrenreich, Fear of Falling: The INNER Life of THE Middle Class 15 (1989).

9. George R. Catlett \& Norman O. Olson, Accounting for Goodwill 20 (1968). 
equipment in a productive unit, and systems, controls, and methods developed as part of the operation.

\section{The Life of Goodwill: Its Duration and Vigor}

Unlike tangible productive resources, goodwill is not consumed in production. Its value may rise and fall over the course of its life in response to extrinsic as well as intrinsic factors. ${ }^{10}$ If, for example, a competitor's business fails, the value of one's goodwill may rise. If a new competitor enters the field, the value of one's goodwill may fall. Although presumably finite, the life of goodwill is indeterminate. ${ }^{11}$

While it is difficult to estimate the life and continuing vigor (both depreciation and appreciation) of goodwill, buyers regularly attempt to do so in market transactions when they purchase goodwill. Rational buyers are willing to pay only for the goodwill they are purchasing, not the goodwill they will later generate themselves. Hence, every market sale of goodwill reflects the buyer's and seller's estimate of the life and vitality of the purchased goodwill. (The buyer is also purchasing access to an auspicious opportunity to develop his own goodwill, but this opportunity inheres in the already-existing business and should be considered an aspect of the business's current goodwill. ${ }^{12}$ ) Thus, to the extent we rely upon comparable market sales or market capitalization rates ${ }^{13}$ (however adjusted) to value goodwill at divorce, as we normally do, we need not confront the dual issues of the life and vitality of goodwill.

Nevertheless, it is analytically helpful to reconstruct from scratch the valuation of a finite stream of future earnings. The ensuing discussion is proposed as an exercise, not as a valuation technique. Because capitalization rates are best derived from market sales of goodwill, much of the content of this exercise is short-circuited in valuation by recourse to market capitalization rates. The purpose of this exercise is to expose and examine the ingredients of those rates in order to help us avoid a number of pitfalls in goodwill valuation.

\section{Rationalizing A Purchase of Goodwill}

Let us assume a business or practice that, over the past five years, has generated average annual excess earnings of $\$ 50,000$, that is, $\$ 50,000$ above and beyond the sum of the market value of the spouse-manager's labor and a reasonable return on all tangible assets and individually quantifiable intangible assets. The potential purchaser believes that he will be able to maintain those excess earnings and is thus willing to offer a price that assumes the continuance

10. Id. at $20-21,85$.

11. Hugh P. Hughes, Goodwill in ACCOUNTING 117 (1982); GlenN M. DESMOND \& Richard E. KELLEY, Business VALUATION HANDBOOK 165 (1980).

12. This opportunity may be described as a component of "likely future growth rate." See Shannon Pratt, Valuing Small businesses and Professional Practices 14-15 (1986).

13. To the extent, however, that we attempt to construct capitalization rates by the summation method, we must address both questions. See infra part IV.C.3. 
of those excess earnings ${ }^{14}$ from presale goodwill of the business. The buyer does not believe that this purchased goodwill will last forever, so he assigns it a life. Arbitrarily, but not unreasonably, he assigns the goodwill a fifteen-year life. ${ }^{15} \mathrm{He}$ does not depreciate the goodwill over its fifteen-year life because goodwill is not consumed in production and it may increase or decrease in value. $^{16}$ Unless the buyer believes that the goodwill has a short life, that is, fewer than ten years, he will not be unduly concerned about the accuracy of his forecast of goodwill life, because discounting to present value will make any error relatively insignificant.

The most important issue for the purchaser is risk, the uncertainty of realizing the expected stream of future excess earnings. Let us assume that the buyer's examination of relative risk factors and alternative investments leads him to conclude that he should require a twenty-five percent annual return on money invested in the business's goodwill. ${ }^{17}$ If the purchased goodwill were to produce excess earnings in perpetuity, the buyer would be willing to pay $\$ 200,000$ for the goodwill. ${ }^{18}$ But the buyer has estimated that the goodwill has a life of fifteen years. So he will wish to obtain a return of twenty-five percent per year on his investment for fifteen years and to recover his original investment. Thus, the capitalization rate includes both an interest rate and a capital recovery rate. ${ }^{19}$

14. For purposes of simplicity, I will here assume no expected inflationary growth in the nominal value of these earnings and no real growth. Capitalization rates, of course, include both types of expected growth.

15. Estimates of between 10 and $\mathbf{4 0}$ years are suggested in the accounting literature.

16. The reader may find our buyer's position on depreciation counterintuitive. Some commentators have proposed, for marital property valuation purposes, that goodwill be understood or treated as a depreciating asset. See, e.g., William A. Reppy, Jr., Major Events in the Evolution of American Community Property Law and Their Import in Equitable Distribution States, 23 FAM. L.Q. 163, 187-89 (1989). See also Kim Cheatum, Professional Goodwill: A Conceptual Approach, 13 FAM. L. NEwS (California State Bar) 34, 47 (1990); Jerald Udinsky, Putting a Value on Goodwill, 9 FAM. L. ADV., Fall 1986, at $37,38-40$.

Whether goodwill should be conceptualized as a depreciating asset will be further discussed in text accompanying notes 94-105 infra. Yet, in view of prevailing valuation practices, it is an academic question because even in excess-earnings valuation, the market-derived capitalization rates applied to annual excess earnings necessarily take into account the anticipated life and depreciation, if any, of the goodwill. See infra text accompanying notes 24-26, 59-66.

17. This buyer is truly starting from scratch. If he observes that buyers in the market are consistently using a certain capitalization rate for earnings from similar goodwill, he may do so himself and stop here.

18. Indeed, he would be willing to pay $\$ 200,000$ if his purchase price were to be restored to him at the end of the 15-year period, that is, if he were, effectively, purchasing a bond or note. The issue for the buyer arises not simply from the difference between perpetual and finite streams but from the combination of a finite stream and the nonreturn of capital.

19. GlenN M. Desmond, How to Value Professional Practices 66-67 (1980). Shannon Pratt, in contrast, attributes this analysis to real estate appraisal but not invariably to business appraisal. For business appraisal, an alternative approach is to recognize either depreciation or a reserve for replacement as an expense. To the extent that earnings do not include reduction for depreciation or replacement reserve, Pratt acknowledges that implicit in the capitalization rate is an extra increment for capital recovery. PRATT, supra note 12, at 125 . The distinction is one of methodology, not of substance.

I have used "capitalization rate" as I have because it is so used in marital property legal and accounting literature and practice: A "cap rate" is used to reduce to present value a finite stream of future earnings from business or professional goodwill. In market comparisons, a "capitalization" rate is inferred by dividing annual excess earnings by the purchase price of the goodwill, the familiar 
The buyer may ascertain the exact amount he should pay by summing the discounted present value of $\$ 50,000$ annual excess earnings for fifteen successive years, using an interest rate of twenty-five percent. His calculation will look like this:

End of Year
1
2
3
4
5
6
7
8
9
10
11
12
13
14
15

Total present value
Present Value of $\$ 50,000$

$40,000^{20}$

32,000

25,600

20,480

16,384

13,107

10,485

8,389

6,711

5,369

4,295

3,436

2,749

2,199

1,759

$\$ 192,963$

The difference between the present value of a perpetual stream of $\$ 50,000$ annually $(\$ 200,000)^{21}$ and a fifteen-year stream $(\$ 192,963)$ is $\$ 7,037$, which invested at twenty-five percent for fifteen years will produce $\$ 200,000$, thus enabling the purchaser to recover his original capital as well as enjoy a twentyfive percent return for fifteen years. The purchaser's effective capitalization rate for a fifteen-year stream is twenty-six percent $(\$ 50,000 \div \$ 192,963)$.

This illustration suggests a number of points. First, if goodwill is considered relatively long-lived, difficulty in precise ascertainment of life is relatively insignificant because of the time value of money. In our illustration, we see that, at a twenty-five percent interest rate, the present value of a fifteen-year stream of $\$ 50,000(\$ 192,963)$ is worth $96.5 \%$ of the present value of a perpetual stream of $\$ 50,000$ a year $(\$ 200,000)$. Shortening the life of the stream a bit, a ten-year

price/earnings ratio. Thus if annual excess earnings are $\$ 25,000$ and the sales price is $\$ 100,000$, the inferred capitalization rate is $25 \%$.

In this discussion, I use terminology and concepts that are familiar to marital property lawyers, judges, and legal academics who are not specially trained in accounting or economics, as I am not. I apologize if my terminology seems awkward or discordant to those trained in other disciplines; I have taken pains to insure that my conclusions are not.

20 . The present value of receiving $\$ 50,000$ a year from now is $\$ 50,000 \div(1$ plus the interest rate expressed as a decimal), or $\$ 50,000+1.25$, which equals $\$ 40,000$. Dividing $\$ 40,000$ by 1.25 yields the present value of receiving $\$ 50,000$ two years from now, which is $\$ 32,000$, and so on.

21. Calculated as follows: present value of perpetual cash flow $=$ annual cash flow divided by the interest rate $=\$ 50,000 / .25=\$ 200,000$. 
stream of $\$ 50,000$ a year has a present value of $\$ 178,525$, or $89.3 \%$ of a perpetuity. Keeping all other facts constant, a purchaser anticipating a ten-year life would use a twenty-eight percent capitalization rate $(50,000 \div 178,525=$ $28 \%$ ). A five-year stream of $\$ 50,000$ a year has a present value of $\$ 134,464$, or sixty-seven percent of a perpetuity. Holding all other facts constant, a purchaser anticipating a five-year life would use a capitalization rate of thirty-seven percent $(50,000 \div 134,464=37 \%)$.

Discussion of goodwill often involves comparison of perpetuities or debt instruments, such as bonds, which reflect only rates of return, and finite streams that reflect rates of return and capital recovery. Such comparisons may lead us to exaggerate the risk factor of goodwill. If, for example, we observe that treasury bills are yielding eight percent and that $X Y$ variety goodwill is selling for four times annual excess earnings (twenty-five percent capitalization rate), we should not conclude that the purchaser of XY variety goodwill believes it to be three times riskier than a treasury bill. If, for example, the buyer has also assigned the goodwill a five-year life, the buyer has effectively assigned it an interest rate of $1623 \%$. He believes XY goodwill is twice as risky as a treasury bill but in order to recover $1623 \%$ annual return and his capital investment at the end of five years, he must insist upon a twenty-five percent capitalization rate.

Considerable confusion is created by the frequent practice of converting the capitalization rate, a percentage, into its mathematical reciprocal. Application of this multiple or multiplier ${ }^{22}$ to annual excess earnings, creates the impression that what has been derived is a perpetuity, which in turn invites what may often be inappropriate (double-discounting) reduction for limited life and depreciation. ${ }^{23}$ The multiple may also be misunderstood as an estimate of the useful life of the asset (for example, a multiple of three suggests a three-year life). ${ }^{24}$ This misunderstanding leads to unwarranted claims that the figure derived should be further discounted to present value.

In summary, this exercise in reconstructing a purchase of goodwill reminds us that the goodwill capitalization rates that we observe in the market embody capital recovery as well as interest rates. Most importantly, to the extent that direct market transactions are the immediate basis for our capitalization rate, ${ }^{25}$ we should not further reduce the market-derived figure for the finite life and arguable depreciation of goodwill. The market has already embodied both in the

22. The multiple, or multiplier, is simply the multiplicative inverse, or reciprocal, of the capitalization rate. The multiplicative inverse of a number (a) is that number (b) which will yield 1 when multiplied by a. For example, $25 \%$ may equally be expressed as the fraction $1 / 4$. The multiplicative inverse of $1 / 4$ is 4 . Thus the capitalization rate of $25 \%$ may be alternatively expressed as the multiple, or multiplier, 4.

Presumably this conversion is done because people feel more comfortable multiplying by 4 than dividing by $25 \%$. This convenience, however, would seem to be offset by the mystification and confusion engendered by the use of a multiple.

23. See, e.g., Cheatum, supra note 16 , at 47.

24. See infra note 134 .

25. This valuation method, direct market comparison, is discussed infra part IV.C.2. 
capitalization rate: The buyer pays only for what he believes he is receiving from the seller; he does not pay for the value of his own future labor. ${ }^{26}$ More generally, this reconstruction invites us in thinking about goodwill to distinguish between risk and life, and it cautions us about comparability when we contemplate alternative investments. If buyers assume a relatively long life for goodwill, ten years or more, the life of the asset plays a relatively insignificant role in the capitalization rate. If, on the other hand, buyers of goodwill assume a relatively short life, and we compare the capitalization rates of goodwill to benchmark investments such as bonds and stocks, we are likely to overestimate the risk that the market perceives in goodwill.

\section{E. The Sale of Goodwill from the Seller's Perspective-Tax Considerations}

This section will compare, from the buyer's and seller's perspectives, the income tax incidents of realization of future income attributable to purchased goodwill. ${ }^{27}$ The purpose of this comparison is to examine the frequently made assertion, in divorce valuation, that excess earnings should be reduced for tax consequences before the earnings are reduced to present value. In our illustrative case, this would mean that the $\$ 50,000$ annual excess earnings should be reduced to $\$ 30,000$ annual excess earnings to reflect application of the earner's marginal combined federal/state personal income tax rate-assumed here to be forty percent-and the capitalization rate should be applied to this tax-reduced figure of $\$ 30,000$.

Let us assume that, as above, the seller-wife receives in the marital property distribution $\$ 192,963$ in marital property cash to offset the business goodwill awarded entirely to the buyer-husband. The seller wishes to replicate the buyer's stream of future income attributable to goodwill developed during marriage. She is able to purchase a high risk (twenty-five percent discount rate) instrument with a fifteen-year life that will enable her to derive $\$ 50,000$ income a year by combining the twenty-five percent rate of return with an ever-increasing invasion of capital. Effectively, the seller is purchasing a fifteen-year annuity. The seller's return would be as follows:

\begin{tabular}{|c|c|c|c|c|c|}
\hline End of Year & \multicolumn{2}{|c|}{$25 \%$ Interest } & \multicolumn{2}{|c|}{$\begin{array}{l}\text { Invasion of Principal } \\
\text { (Recovery of Capital) }\end{array}$} & Remaining Principal \\
\hline 1 & 48,241 & + & 1,759 & $=50,000$ & 191,204 \\
\hline 2 & 47,801 & & 2,199 & & 189,005 \\
\hline 3 & 47,251 & & 2,749 & & 186,256 \\
\hline
\end{tabular}

26. Shannon Pratt, discussing the relationship between expected growth and the rate used to capitalize current earnings, observes that the "buyer would not expect to pay for potential future growth that may result from his own successful entrepreneurial efforts." PRATT, supra note 12, at 133. See also id. at 161 .

27. In divorce, the "seller" is the nonbusiness spouse, who generally makes a nontaxable transfer of her marital property interest in the goodwill to the business spouse. Interspousal property transfers incident to divorce are not taxable events. I.R.C. \& 1041(c)(2) (1988); see also Treas. Reg. \$ 1.1041-1T (1985). 


$\begin{array}{rrrr}4 & 46,564 & 3,436 & 182,820 \\ 5 & 45,705 & 4,295 & 178,525 \\ 6 & 44,631 & 5,369 & 173,156 \\ 7 & 43,289 & 6,711 & 166,445 \\ 8 & 41,611 & 8,389 & 158,056 \\ 9 & 39,514 & 10,486 & 147,570 \\ 10 & 36,892 & 13,108 & 134,462 \\ 11 & 33,615 & 16,385 & 118,077 \\ 12 & 29,519 & 20,481 & 97,596 \\ 13 & 24,399 & 25,601 & 71,995 \\ 14 & 17,999 & 32,001 & 39,994 \\ 15 & 9,999 & 39,994 & 0\end{array}$

When we compare the future streams of $\$ 50,000$ annually in the hands of the buyer and seller, we see that they both contain taxable income. The buyer's tax experience is different from the seller's only insofar as the seller makes a nontaxable recovery of capital. The inequality thus arises from the seller's nontaxable recovery of basis, not from the more ubiquitous taxability of future income. In fact, the income generated by almost all assets is taxable. Interest rates normally contemplate taxable streams of income. To the extent that income is nontaxable (for example, income from a municipal bond), commensurately lower interest rates are used.

In terms of inequality of basis, the issue seems to vanish when we contemplate perpetuities. Unequal basis is immaterial so long as the perpetuities are held for the production of income, all of which is taxable. Differential basis may matter, however, upon the sale of perpetuities. The problem of differential basis is ubiquitous in community property distribution. It is not peculiar to goodwill. In our example, the "seller" received an offsetting award in cash, a form of payment that gives her a $100 \%$ basis. Had she received instead a low-basis form of payment, such as an appreciated home or appreciated stock, basis inequality would diminish and might even disappear. ${ }^{28}$

Even in our case, what looks at first glance like a substantial difference in the tax posture of buyer and seller turns out to be trivial when we discount tax effects to present value. The present value of the basis recovery tax savings

28. Suppose, for example, that the equity in the couple's heavily encumbered co-owned home is $\$ 200,000$ and is equal to the value of the goodwill of the husband's marital property business, and that the wife is awarded the home while the husband is awarded the business. Further suppose that the couple purchased the home for $\$ 200,000$ and its fair market value at divorce is $\$ 400,000$. If the wife subsequently sells the home (and is not able to take advantage of the tax roll over provisions), she will realize $\$ 200,000$ taxable gain on the sale. In this situation, the husband and wife are equally circumstanced: Each will be taxed on $\$ 200,000$ gain when he or she realizes the value of the asset assigned to him or her at divorce.

See generally Michael Asimow, The Assault on Tax-Free Divorce: Carryover Basis and Assignment of Income, 44 TAX L. REV. 65, $71-78$ (1988). 
experienced by the seller vis-à-vis the buyer is $\$ 8,430$, or four percent of the purchase price.

$\begin{array}{cccc}\text { End of Year } & \begin{array}{c}\text { Invasion } \\ \text { of Principal } \\ \text { (Recovery of Capital) }\end{array} & \begin{array}{c}\text { Combined } \\ \text { Marginal Rate }\end{array} & \begin{array}{c}\text { Present Value } \\ \text { of Tax Savings }\end{array} \\ 1 & 1,759 & 703 & 562 \\ 2 & 2,199 & 879 & 562 \\ 3 & 2,749 & 1,099 & 562 \\ 4 & 3,436 & 1,374 & 562 \\ \ldots & & & \ldots \\ 15 & 39,994 & 15,998 & 562 \\ & & & 8,430\end{array}$

This analysis should dispel the frequent but incorrect intuition that excess earnings should be reduced for tax consequences before the earnings are reduced to present value: in our example, the intuition that $\$ 50,000$ annual excess earnings should be reduced to $\$ 30,000$ to reflect application of the earner's forty percent marginal combined personal income tax rate. This common intuition is incorrect because virtually all assets generate taxable income. We do not, for example, discount the value of marital property cash distributions because the cash will generate future taxable income. ${ }^{30}$ Insofar as the capitalization rates we use contemplate the receipt of taxable income, we should not discount excess earnings for the tax consequences they will produce.

A somewhat different and narrower issue may arise when capitalization rates are derived from particular market sales of goodwill, and accounting practice in those particular sales has been to capitalize only after-tax ${ }^{31}$ earnings. In such a case it would be inappropriate to apply the same capitalization rate to pretax earnings. The issue, however, becomes the choice of an appropriate capitalization rate, not whether, as a matter of general principle, future expected earnings from goodwill should be tax-reduced. ${ }^{32}$

29. I have used a $25 \%$ discount rate on the theory that the risk of taxation is the same as the risk of realization of the earnings subject to taxation.

30. I thank my colleague Michael Asimow for this observation.

31. The term "after-tax" is ambiguous. Accounting texts seem to use it to refer to nonpersonal taxes that serve to reduce business income. See, e.g., PRATT, supra note 12, at 88, 89, particularly 83: "Such returns are after corporate income taxes, but would be taxable to the investor at the time that the investor actually realized the return." Yet the issue generally posed at divorce is application of the spouse's personal income tax rates to net business income.

Describing current accounting valuation practice, Shannon Pratt reports: "When valuing a large corporation, you usually state earnings and cash flow figures on an after-tax basis. When valuing small businesses and professional practices, the opposite usually is true; that is, you usually state earnings and cash flow figures on a pretax-basis." Id. at 36. See also id. at 146.

32. "The income stream to be capitalized can come either before or after any or all of several items, such as interest, depreciation [and] taxes .... The key is that the income stream to be capitalized must be clearly defined and the capitalization rate or multiple chosen must be a rate that is appropriate for the particular income stream that is defined." Id. at 88.

In some states, courts disallow consideration of tax consequences that are "speculative" or "not immediate." See, e.g., Marriage of Fonstein, 17 Cal. 3d 738, 552 P.2d 1168, 131 Cal. Rptr. 873 (1976). 
II

\section{PROFESSIONAL AND COMMERCIAL GOODWILl AS AN ASSET AT DIVORCE: What ARE We TRYING TO MEASURE?}

In the United States today, a sharp division exists in case law, commentary, and professional opinion on whether market transferability should establish the limits of goodwill recognition at divorce. A majority of states that have been presented with the issue ${ }^{33}$ recognize nonmarketable as well as marketable

This valuation rule has been equally applied to taxation incident to the flow of future income from assets awarded to the spouses at divorce. See, e.g., Marriage of Marx, 97 Cal. App. 3d 552, 159 Cal. Rptr. 215 (1979) (future income taxation of pension benefits should be ignored in valuing a pension interest); accord, Marriage of Bergman, 168 Cal. App. 3d 742, 214 Cal. Rptr. 661, 669 (1985). Such case law, which requires that valuation methods consider only pretax income, does not however control the choice, in an appropriate case, of the discount rate to be applied in order to insure valuation comparability.

33. I include jurisdictions that capitalize excess earnings and accept valuation figures that are not supportable by reference to actual market sales. Some courts explicitly acknowledge the implication of this practice (see cases cited infra note 34); others do not (see infra text accompanying notes 35-39). States approving capitalization as a method of valuing goodwill include Arizona: Mitchell v. Mitchell, 732 P.2d 208, 211 (Ariz. 1987); California: Marriage of Hargrave, 163 Cal. App. 3d 346, 209 Cal. Rptr. 764 (1985); Mueller v. Mueller, 144 Cal. App. 2d 245, 252, 301 P.2d 90, $95-96$ (1956). Although the California Supreme Court has never directly addressed the valuation of goodwill at divorce, it cited the divorce capitalization cases approvingly in the eminent domain case of People v. Muller, 36 Cal. 3d 263, 271, 203 Cal. Rptr. 772, 777 (1984);; Colorado: Marriage of Keyser, 820 P.2d 1194, 1196 (Col. Ct. App. 1991); Marriage of Martin, 707 P.2d 1035, 1037 (Col. Ct. App. 1985); Idaho: Loveland v. Loveland, 422 P.2d 67, 69-70 (Idaho 1967) (dictum); Indiana: Porter v. Porter, 526 N.E.2d 219 (Ind. Ct. App. 1988); Kentucky: Clark v. Clark, 782 S.W.2d 56, $59-60$ (Ky. Ct. App. 1990); Michigan: Kowalesky v. Kowalesky, 384 N.W.2d 112, 116 (Mich. Ct. App. 1986); Minnesota: Nelson v. Nelson, 411 N.W.2d 868, 873 (Minn. Ct. App. 1987); Montana: Marriage of Hull, 712 P.2d 1317, 1322 (Mont. 1986); Nevada: Ford v. Ford, 782 P.2d 1304, 1309 (Nev. 1989); New Jersey: Dugan v. Dugan, 457 A.2d 1, 9 (N.J. 1983); see also Piscopo v. Piscopo, 555 A.2d 1190 (N.J. Super. Ct. App. Div. 1988), aff'd, 557 A.2d 1040 (N.J. Super. Ct. Ch. Div.), cert. denied, 564 A.2d 875 (N.J. 1989) (recognizing celebrity "goodwill" as marital property at divorce); New Mexico: Hurley v. Hurley, 615 P.2d 256, 259 (N.M. 1980), overruled on other grounds by Ellsworth v. Ellsworth, 637 P.2d 564 (N.M. 1981); but consider Hertz v. Hertz, 657 P.2d 1169, 1174 (N.M. 1983) and Cox v. Cox, 775 P.2d 1315 (N.M. Ct. App.), cert. denied, 776 P.2d 846 (N.M. 1989); New York: Finocchio v. Finocchio, 556 N.Y.S.2d 1007, 1009 (N.Y. App. Div. 1990); see also Elkus v. Elkus, 572 N.Y.S.2d 901, 903-04 (N.Y. App. Div. 1991) (celebrity "goodwill" is marital property distributable at divorce); North Carolina: McLean v. McLean, 374 S.E.2d 376, 385 (N.C. 1988), approving Poore v. Poore, 331 S.E.2d 266 (N.C. Ct. App.), rev denied, 335 S.E.2d 316 (N.C. 1985); compare Sonek v. Sonek, 412 S.E.2d 917, 919 (N.C. Ct. App. 1992) (salaried employee has no goodwill for purposes of distribution at divorce); Ohio: Kahn v. Kahn 536 N.E.2d 678, 680-83 (Ohio Ct. App. 1987), but see Josselson v. Josselson, 557 N.E.2d 835, 840 (Ohio Ct. App. 1988), appeal dismissed, 536 N.E.2d 381 (Ohio 1989); Oregon: Marriage of Goger, 557 P.2d 46, 47 (Or. Ct. App. 1976); Utah: Gardner v. Gardner, 748 P.2d 1076, 1080 n.1 (Utah 1988); Sorenson v. Sorenson, 769 P.2d 820, 826 (Utah Ct. App.), cert. granted, 779 P.2d 688 (Utah 1989); Virginia: Russell v. Russell, 399 S.E.2d 166, 169-70 (Va. Ct. App. 1990); Bosserman v. Bosserman, 384 S.E.2d 104, 107-09 (Va. Ct. App. 1989); Washington: Marriage of Hall, 692 P.2d 175, 180-81 (Wash. 1984) (en banc); Marriage of Fleege, 588 P.2d 1136, 1138-40 (Wash. 1979). 
goodwill. ${ }^{34}$ A minority of states ${ }^{35}$ take a more restrictive view and recognize only goodwill that can be transferred in the market.

Although the difference between these two positions may be couched in terms of valuation technique, the distinction is more profound. It is less a question of how to value than what to value. Market transfer valuation accords asset recognition only to that goodwill that can survive a market transfer, while earnings capitalization recognizes nontransferable as well as transferable goodwill. This distinction may be relatively obvious in jurisdictions recognizing only goodwill that can be transferred in the market. But in jurisdictions that purport to recognize all goodwill, discussion of valuation techniques often obscures the underlying point that, with goodwill, different techniques are likely to measure different assets. ${ }^{36}$ Hence we should be entirely unsurprised that capitalization of the excess earnings of a professional practice may yield a goodwill figure far in excess of market offers. ${ }^{37}$

In recent years, a few courts have straddled both positions by requiring transferability as a threshold requirement for goodwill recognition but then, once that requirement has been satisfied, allowing capitalization of excess earnings as one of several permissible valuation techniques. ${ }^{38}$ This posture is conceptually incoherent for those many cases of professional and small-business goodwill where only a portion of goodwill would survive market transfer. In such cases,

34. For explicit recognition of this point, see, e.g., Golden v. Golden, 270 Cal. App. 2d 401, 405, 75 Cal. Rptr. 735, 738 (1969); Hurley, 615 P.2d at 259; Ford, 782 P.2d at 1310; Marriage of Lukens, 558 P.2d 279, 281 (Wash. 1976).

35. The following states recognize and value goodwill at divorce only insofar as it is transferable: Arkansas: Wilson v. Wilson, 741 SW.2d 640, 646 (Ark. 1987), appeal after remand, 781 S.W.2d 487 (1989); Florida: Thompson v. Thompson, 576 So.2d 267, 270 (Fla. 1991); Hawaii: Antolik v. Harvey, 761 P.2d 305, 308-09 (Haw. 1988); Kansas: Winn v. Winn, 482 P.2d 16, 21 (Kan. 1971); Maryland: Prahinski v. Prahinski, 582 A.2d 784, 790 (Md. 1990); Missouri: Hanson v. Hanson, 738 S.W.2d 429, 436 (Mo. 1987) (en banc); Nebraska: Taylor v. Taylor, 386 N.W.2d 851, 859 (Neb. 1986); Pennsylvania: McCabe v. McCabe, 575 A.2d 87, 89 (Pa. 1990); Fexa v. Fexa, 578 A.2d 1314, 1317 (Pa. 1990); see also De Masi v. De Masi, 530 A.2d 871, 881 (Pa. 1987), appeal denied, 539 A.2d 811 (1988), on subsequent appeal, 597 A.2d 101 (1991); Beasley v. Beasley, 518 A.2d 545, 557 (Pa. Super. Ct. 1986), appeal denied, 533 A.2d 90 (Pa. 1987); Tennessee: Smith v. Smith, 709 S.W.2d 588, 591-92 (Tenn. Ct. App. 1985); Texas: Nail v. Nail, 486 S.W.2d 761, 763 (Tex. 1972); Wisconsin: Peerenboom v. Peerenboom, 433 N.W.2d 282, 284 (Wis. Ct. App. 1988); see also Sommerfield v. Sommerfield, 454 N.W.2d 55, 61 (Wisc. 1990) (valuation "would turn in part" on saleability); compare Prahinski, 582 A.2d 784 (attorney goodwill had zero value because canons of ethics prohibited its sale) with Hollender v. Hollender (Md. App. 1991) (dentist had goodwill of value at divorce because professional ethics did not bar sale).

36. For explicit discussion of this point, see cases cited supra note 34.

37. In jurisdictions, like California, that purport to recognize nontransferable as well as transferable goodwill, but are, in case law, agnostic or confused about valuation methodology, wide variance between capitalization measures and market sales prices may be given unwarrantedly sinister explanations. Variance may be variously interpreted to demonstrate the unreliability of "hired-gun" forensic accountants or of the valuation techniques themselves. Such interpretations were frequently expressed at the California goodwill colloquia. See infra text accompanying notes 67-68.

38. See, e.g., Moffitt v. Moffitt, 749 P.2d 343, 347-48 (Alaska 1988) (overruling Rostel v. Rostel, 622 P.2d 429, 430-31 (Alaska 1981), which recognized unmarketable professional goodwill); Eslami v. Eslami, 591 A.2d 411, 418-19 (Conn. 1991); Taylor v. Taylor, 386 N.W.2d 851, 859 (Neb. 1986). 
excess-earnings capitalization may capture all goodwill, the nontransferable as well as transferable. ${ }^{39}$

This section compares and evaluates the two polar positions. Because the more generous approach subsumes the narrower position, this section begins with the former and examines the latter as it attempts to impose and rationalize market-transferability limits on goodwill recognition at divorce.

\section{A. Exposition and Evaluation of the Position that Goodwill May Be Measurable by Excess Earnings and Need Not Be Marketable To Be Cognizable at Divorce}

The majority perspective, based on principles of economics and accounting, understands goodwill as an intangible asset that may generate future earnings. The majority position draws its understanding from market transactions and considers them highly instructive, but does not limit recognition to goodwill that can be transferred in the market. In observing certain businesses and many professional practices, the majority notes that much reputation and continuing patronage may not survive a transfer because, for example, faithful patients or customers cannot be relied upon to return to a substitute physician or hair stylist. Thus, even when there is a market for the goodwill, the market may understate the value of the goodwill in the goodwill-developer's hands.

The majority thus favors capitalization of excess earnings when the business or practice will remain in the business or professional spouse's hands. It wishes to measure as accurately as possible the value of that goodwill in the spouse's hands. It would accept market-sales valuation as an exhaustive measure only if market-sales valuation could answer the following question: What would a

39. In theory, it is possible to reconcile market sales prices and capitalization measures because they both derive ultimately from market transactions. Nevertheless, even a casual reading of divorce-related goodwill capitalization cases reveals that capitalization is not used to establish a market-obtainable price, but rather to assess the value of the goodwill in the originator's hands. See cases cited supra note 33. When this point is not explicitly articulated or recognized, case law discussion tends to become opaque and incoherent. See, e.g., Marriage of Fleege, 588 P.2d 1136 (Wash. 1979) (en banc); Marriage of Slater, 100 Cal. App. 3d 241, 160 Cal. Rptr. 686 (1979); Marriage of Foster, 42 Cal. App. 3d 577, 117 Cal. Rptr. 49 (1974). 
similarly qualified buyer pay to become Dr. Spouse, if that were possible $?^{40}$ Since that is not possible, market sales are likely to understate value.

The proponent of capitalization is not concerned that present goodwill value derived from capitalization is essentially a projection of future earnings. $\mathrm{He}$ responds that the value of any asset is its capacity to produce future income. $\mathrm{He}$ is comfortable dividing Dr. Spouse's postdivorce income into several streams: one is a return on Dr. Spouse's separate property labor; another represents a return on tangible and separately identifiable intangible assets; another is a return on maritally developed goodwill; and yet another is a return on postdivorce ${ }^{41}$ separate property goodwill.

Nor is he concerned that the full value of Dr. Spouse's marital goodwill cannot and will not be realized without the application of Dr. Spouse's postdivorce labor. He knows that Dr. Spouse generally can be relied upon to continue to work in his practice and, if he does so, the return on goodwill should not be counted economically as a return on separate labor, but rather on marital goodwill. He further responds that if Dr. Spouse has a satisfactory reason to discontinue work, for example, he is approaching retirement age, the life of his nonmarketable goodwill must be calculated accordingly. If Dr. Spouse has a less compelling reason to discontinue practice, he may present it and allow the law to balance the competing claims of waste, on behalf of the marital estate, and personal autonomy, on behalf of Dr. Spouse. Some would seriously pause at such a claim. Others would simply assign Dr. Spouse his goodwill and allow him either to waste or exploit it as he likes. In any event, midcareer discontinuation of a successful practice is a rare and hypothetical case, a tail that should not wag

40. Some readers may balk at this formulation, fearing that it may improperly capture Dr. Spouse's postdivorce labor as well as his marital goodwill. The key to the formulation is in the term similarly qualified buyer, a person whose labor is equally valuable but who is not the originator of the goodwill. That a market purchaser is unable to reap the full measure of Dr. Spouse's goodwill need not reflect the quality of the buyer's labor but rather the difficulty of transferring goodwill from its originator to a successor when the goodwill-holder has a personal relationship with his clients. In such a case, the transfer alone is disruptive, in part because the transfer may cause the clients to feel loss and desertion and because they may fear that the successor will not adequately replace the goodwill-originator. In the case of an internist, for example, some patients may not return at all to discover whether the successor suits them and others may experience keen loss and disappointment in the very experience of returning to a familiar place with an unfamiliar successor. Others, who were not fully satisfied with Dr. Spouse but were insufficiently motivated to find a new internist, may do so now that the continuity of relationship has, in any event, been disrupted. All of these patients would have continued with Dr. Spouse but will be lost to his successor through no inadequacy of his own.

If becoming Dr. Spouse still seems extravagant, the reader may substitute an equivalent formulation quoted in the text infra note 57: At divorce we are "seek[ing] to discover what a willing buyer would pay to a willing seller giving no consideration to the impediments of transfer." Or, we may simply say that we are trying to capture the value of the goodwill in the goodwill-developer's hands.

41. In most jurisdictions, the marital economic community ends at divorce. Yet in some states, the marital economic community ends at permanent physical separation or the filing of the divorce complaint. Cal. Civil CODE \$ 5118 (1983); WASH. Rev CodE \$ 26.16.140 (West 1988); Suter v. Suter, 546 P.2d 1169, 1174-75 (Idaho 1976) (economic community ends at separation); Schanck v. Schanck, 717 P.2d 1, 3 (Alaska 1986); Brandenburg v. Brandenburg, 416 A.2d 327, 333 (N.J. 1980); Jolis v. Jolis, 446 N.Y.S.2d 138, 140 (1981), affd, 470 N.Y.S.2d 584 (1983) (economic community ends at filing of divorce complaint). 
the dog. Most favorably to Dr. Spouse, it may be understood to present a remedial claim.

\section{B. Exposition and Evaluation of the Minority Position that Marital Property Recognition Should Be Limited to Marketable Goodwill}

Case law and commentary advance many arguments in favor of recognizing only marketable, as opposed to nontransferable goodwill, and hence imposing a market-sales lid on goodwill valuation. Although some of these arguments seem more aptly supportive of the position that no goodwill be treated as property divisible at divorce, they are all advanced to support a distinction between marketable goodwill and nonmarketable goodwill.

1. Postdivorce Earnings are the Earner's Separate Property. Market-lid proponents point out that all American marital property systems characterize a spouse's postdivorce earnings as his separate property. ${ }^{42}$ Hence any marital property measurement technique that purports to capitalize a spouse's postdivorce earnings is prima facie impermissible. Yet any valuation of goodwill is a projection of future earnings, ${ }^{43}$ whether that goodwill is established by comparable market sales or capitalization of excess earnings. This response is powerful, because even if we were to put a market lid on the value of Dr. Spouse's goodwill, we do not expect him to sell the practice but anticipate instead that he will recover from future postdivorce earnings the value we have ascribed to the goodwill. Thus, to the extent full valuation, or capitalization, violates the separate property character of postdivorce earnings, market valuation does so as well.

The essential weakness of the postdivorce earnings argument is that the present value of any asset is its capacity to generate future earnings. The concept of "earnings" must therefore be glossed by general marital property principles, which trace earnings to their discrete sources to determine whether the earnings are separate or marital in character. To the extent that postdivorce earnings are generated by a marital asset, they are marital property. To the extent that they are generated by a spouse's postdivorce labor, they are his separate property. It is precisely this allocation that the excess-earnings formula addresses when it attempts to distinguish between postdivorce labor allocable to the laboring spouse alone and excess earnings attributable to stores of marital goodwill. In contrast, the postdivorce earnings argument effectively assumes away marital goodwill as a source of postdivorce earnings. It implicitly insists, without argument or demonstration, that all postdivorce returns are attributable to postdivorce labor alone.

42. Id.

43. Dugan v. Dugan, 457 A.2d 1, 6 (N.J. 1983). 
2. Goodwill Should Not Be Recognized to the Extent It Is Inalienable or Illiquid. Market-sales-lid proponents may argue that goodwill should not be recognized to the extent that it is inalienable or, alternatively, illiquid. These two claims are similar, but perhaps distinguishable. The first claim is that alienability is a necessary condition for marital property recognition; that is, wealth may not be defined as property and hence be subject to marital property distribution unless it is alienable, and market value defines the limits of alienability. Doctrinally, this assertion is, at least superficially, incorrect. Pensions, vested and unvested, are inalienable, but we nevertheless count them as property for marital property purposes, including distribution at divorce. ${ }^{44}$ Other interests may also be inalienable, for example, life estates, yet we also count them as property. Alienability per se is clearly not a prerequisite to marital property classification.

Yet those who would impose a market-sales lid on goodwill value may respond that it is not alienability per se but rather the cause of the inalienability that compels their conclusion. Pensions and other inalienable interests that are counted as marital property are inalienable not because of intrinsic market limitations, but because their creators or the law have attached a condition of inalienability. If, for example, pension rights were not rendered inalienable by contract, we could imagine a market in pensions. Nonmarketable goodwill, in contrast, is generally inalienable $e^{45}$ because it is economically inseparable from the spouse who developed it. Thus the inalienability objection may be understood to express a concern about valuing wealth that is inseparable from the person of the spouse who developed it. This objection will be analyzed separately below.

The second related concern is that the goodwill is illiquid to the extent that its capitalized value is greater than a market sale would support. The goodwill developer may not cash out in the market. Instead, he must continue after divorce to work in the business or practice in order to realize the value he has already been charged in the marital property distribution. Again, this is not a

44. For a state-by-state account, see Grace Ganz Blumberg, Intangible Assets: Recognition and Valuation, in 2 VALUATION AND DISTRIBUTION OF MARITAL PROPERTY $\$ 23.02$ (John McCahey ed. 1988).

45. There also may be other narrower causes of inalienability. Some otherwise marketable professional goodwill may be inalienable because the law prohibits its transfer. See, e.g., Sidall v. Keating, 185 N.Y.S.2d 630, affd, 164 N.E.2d 860 (1959), discussed in Hirschfeld v. Hirschfeld, 8 Fam. L. Rptr. (BNA) 2403 (N.Y. Sup. Ct. 1982) (goodwill of attorneys). See also Marriage of Fleege, 588 P.2d 1136 (1979) (en banc) (dental goodwill). Partnership goodwill may be inalienable because its holders have entered a buy-sell agreement to control partner departure from the firm. See, e.g., Marriage of Slater, 100 Cal. App. 3d 241, 160 Cal. Rptr. 686 (1979); Clark v. Clark, 782 S.W.2d 56, 60 (Ky. Ct. App. 1990); Marriage of Keyser, 820 P.2d 1194, 1196-97 (Colo. Ct. App. 1991).

Jurisdictions that impose a market-sales lid on goodwill valuation at divorce may take into account such restraints on alienation; those that recognize nontransferable as well as transferable goodwill should not treat such alienation restraints as controlling at divorce valuation. Contrast, e.g., Sweeney v. Sweeney, 534 A.2d 1290 (Me. 1987) and Saint-Pierre v. Saint-Pierre, 357 N.W.2d 250, 256 (S.D. 1984) with Marriage of Slater, 100 Cal. App. 3d 241, 160 Cal. Rptr. 686 (1979) and Clark v. Clark, 782 S.W.2d 56, 60 (Ky. Ct. App. 1990). 
unique predicament in marital property law. Far more frequently, a spouse with an unvested pension is put to the same choice. The pension has been assigned and charged to its earner at divorce, but it will be valueless unless the earner continues in his present job until the pension vests. The spouse assigned his own unvested pension thus chooses whether to preserve its value or to relinquish it, presumably for a better opportunity.

The concern here reduces to the issue of personal autonomy: To the extent that the goodwill holder cannot realize the ascribed value of the goodwill, he is locked into his business or practice after divorce. Or, he must bear alone the entire cost of relinquishing his goodwill in order to capture other opportunities. One can look at this variously as an economic efficiency, a fairness, and a human liberty issue. From the perspective of economic efficiency, the goodwill holder ought to internalize the entire postdivorce cost of relinquishing his goodwill when he considers alternative postdivorce opportunities. If, for example, we were to adopt a rubric that allowed him to shift one-half of the cost to his former spouse (a wait-and-see payout, for example, for the value of goodwill if and when realized), then he would effectively be enabled to purchase a new opportunity at one-half its true economic cost. His former spouse would be funding the other half. ${ }^{46}$ Alternatively, this may be understood as an issue of fairness. His former spouse would effectively pay half the cost of his new opportunity but would reap no benefit.

A measure of value tied to a spouse's postdivorce labor in a specific business or practice may, however, seem objectionable as a constraint upon personal liberty. This concern is not negligible, but must be weighed against competing claims of economic efficiency and fairness to the nonbusiness spouse. The personal autonomy concern may, in any event, be more narrowly understood to present a remedial problem in cases where career changes are proximately contemplated rather than an objection to the entire enterprise of valuing goodwill in the goodwill-developer's hands.

Moreover, if we were to impose a market lid on the valuation of goodwill that is not fully marketable, autonomy interests would not be substantially advanced because powerful economic factors in any event argue against cashing out: Given the impediments to market transfer, the goodwill is worth more to the originator than to a buyer. Indeed, it is only when the market sales price of goodwill fully captures its value to the originator that he is not subject to this economic pressure to retain and exploit the goodwill he has developed. Thus, a market lid on goodwill that is only partially transferable will make the practitioner wealthier at divorce but is unlikely to enhance his personal autonomy, which is constrained more by the fact of possessing nontransferable goodwill than by whether it is valued at divorce.

46. This issue was presented in Marriage of Marron, 170 Cal. App. 3d 151, 215 Cal. Rptr. 894 (1985) (review denied and ordered depublished by the California Supreme Court Sept. 25, 1985). 
3. Imposing a Market Lid on Valuation Avoids Problems of Double-Dipping. This section assumes, arguendo, that double-dipping ${ }^{47}$ is a problem and explores the frequent assertion that establishing a market-price lid for goodwill avoids double-dipping problems. Market-lid proponents seem to perceive no doubledipping problem when valuation is limited to marketable goodwill because the practitioner has both a stream of future income plus the option to realize, through sale, the present value of the stream of future income attributable to that marketable goodwill.

But the practitioner with marketable goodwill cannot enjoy both. He may either realize the market value of his marital goodwill or retain the practice and enjoy the stream of future income as it is earned. If he retains the practice, as he generally does, he is in the same position as the practitioner with recognized nonmarketable goodwill. In the property division, he has bought out his spouse's marital property present interest, however valued, in the stream of future goodwill earnings. Yet his support liability is based upon his future earnings, which include a return on goodwill. That he could have sold his practice and realized the market value assigned to goodwill at divorce would seem small consolation to the practitioner who maintains his practice after divorce. To the extent he is legitimately aggrieved, he is equally so with the practitioner whose nontransferable goodwill was valued by the capitalization method. In the unlikely event that the holder of marketable goodwill does decide to sell his practice, he is hardly better off. When he invests the proceeds from the sale of the goodwill, the income generated is available for spousal support, as are all his earnings from whatever new practice or job he undertakes. Thus the doubledipping issue is unaffected by the method selected or allowed to value goodwill. So long as we recognize any goodwill as distributable property, we have to deal with double-dipping, which will be treated exhaustively in a separate section. ${ }^{48}$

4. Good Accounting Practice Teaches Us that We Should Not Recognize Any Goodwill that Is Not Marketable. Traditional accounting theory does not enter goodwill on the books unless the goodwill was purchased in a market transaction. This is not, however, because traditional accounting theory denies the value of owner-developed goodwill. ${ }^{49}$ The historical concern underlying the no-entry rule was the watering of stock. A company assessing its own value might misrepresent its worth by overvaluing its goodwill. ${ }^{50}$ This concern is inapt at divorce, where the adversary posture of the parties tests the value of the

47. Double-dipping refers to the practice of dividing the present value of some portion of future earnings as goodwill in the property division and then counting future earnings, when earned, as available for spousal support. Double-dipping is treated exhaustively infra part IV.E.

48. See infra part IV.E.

49. Compare Ira H. Lurvey, Professional Goodwill at Marital Dissolution: Is it Property or Just Another Name for Alimony?, 52 CAL. ST. B.J. 27, 29 (1977).

50. HUGHES, supra note 11 , at 29-30. 
goodwill. More recent accounting justifications for the no-entry rule also have no bearing on valuation at divorce. ${ }^{51}$

Accounting theory does have much to teach us about divorce-related treatment of goodwill, yet its relevance lies not in its bookkeeping methodologies but in its treatment of valuation for prospective buyers. Valuation theory abundantly supports expansive measures of goodwill, including capitalization of excess earnings. ${ }^{52}$

5. Anything in Excess of Market Price Is Personal to the Professional Spouse and Hence Inheres in His Personal Earning Power or His "Human Capital" and Therefore Should Not Be Considered Distributable Property. Market-sales-lid proponents assert that capitalization measures producing values in excess of market-sales prices are simply measuring a spouse's personal earning power, or human capital. This claim is largely answered by the methodology of excessearnings measurement of goodwill, at least in the traditional case of a commercial business or professional practice. The labor credit of the excess-earnings formula, properly measured, assigns to the earner as his separate property all postdivorce proceeds from his personal earning power and human capital.

The question whether nontransferable goodwill inheres in the business or in the practitioner is an implicit battleground in the valuation debate. Those who support capitalization often assume that it inheres in the business or practice, and those who argue for a marketability-only standard assert that it inheres in the person of the businessman or practitioner because it cannot be separated from him in order to effect a transfer to a willing purchaser. In fact, the goodwill inheres in both the business and the practitioner. Both are necessary, and neither is sufficient. The continuance of the business and the goodwilldeveloper's presence are both necessary to reap the full value of the goodwill. The association with a place, a locality, a set of subordinate workers, and a local reputation is what characterizes traditional professional and commercial goodwill. When Dr. San Diego abandons his practice and moves to Chicago, he does not take his goodwill with him. ${ }^{53}$ Nor does it remain in San Diego. It vanishes.

51. See CATLETT \& OLSON, supra note 9, at 68-73. Catlett and Olson point out that the rule serves financial statement objectives by allowing the ready identification of "excess earnings," and they demonstrate the difficulty, in a cost basis system, of accounting for an asset (unpurchased goodwill) for which it is impossible accurately to locate "costs." See also HugHES, supra note 11, at 116.

52. See further discussion infra text accompanying notes 68-94.

53. It is in the newer, emergent claims for goodwill recognition, including celebrity goodwill and employee goodwill, that we see goodwill claims divorced from the traditional setting of a place of business to which old customers, clients, and patients return. This "goodwill," which has no physical roots, is highly mobile. It may even lead a bi-coastal life. But it is not our subject of concern in this portion of the article, which deals with traditionally recognized forms of goodwill. 


\section{The Issue of Symmetry: Returns on Premarital Goodwill During Marriage.} In some community property and equitable distribution jurisdictions, income received during marriage from separate property remains separate property. ${ }^{54}$ Proponents of a market lid argue that under such regimes, nontransferable goodwill recognition at divorce gives rise to an asymmetry unless we also value as separate property the income received during marriage from stores of goodwill accumulated prior to marriage. Stated differently, to the extent that marital goodwill is understood to produce marital income after divorce, so premarital goodwill must be understood to produce separate income during marriage. Because such allocations of income received during marriage are not currently made, it is therefore appropriate to impose a market lid on marital goodwill at divorce.

Yet this argument is fatally overbroad. Assuming, arguendo, this asymmetrical practice, the asymmetry would argue against any recognition of goodwill, not merely the portion that is nontransferable, or nonmarketable.

In any event, the conceptual apparatus for symmetrical treatment is available in the rubric of apportionment of business profits attributable to mixed separate and marital imputs. ${ }^{55}$ That it may not be used is a commentary on practice and, perhaps, perceived fairness rather than any doctrinal incoherence.

\section{Summary}

In summary, the arguments in favor of imposing a market lid seem either unpersuasive or overly broad, in that they equally support nonrecognition of marketable and nonmarketable goodwill. Yet virtually no one advocates universal nonrecognition. ${ }^{56}$ Business or professional goodwill that is marketable at divorce must surely be recognized as a distributable asset. Once this point is conceded, it seems difficult to argue persuasively for a market lid.

54. Under Spanish law, the source of United States community property law, income received during marriage from separate property was characterized as community property; one devoted the product of all one's resources to the marriage and regained exclusive claim to the fruits of separate property only after termination of the marriage. This rule was codified when California became a state. Yet the California Supreme Court early held in George v. Ransom, 15 Cal. 322 (1860), as a matter of constitutional interpretation, that the income received from separate property during marriage remains separate property. Compare Arnold v. Leonard, 273 S.W. 799 (Tex. 1925) (the Texas Supreme Court constitutionalized the Spanish rule). For further discussion of community property states, see WILLIAM A. RePPy, JR. \& CYNTHIA A. SAMUel, CoMmunity PROPERTY IN THE UNITED STATES 11-2 to 11-3 (3d ed. 1991). For discussion of equitable distribution states, see J. THOMAS OLDHAM, DIVORCE, SEPARATION AND THE DisTRIBUTION OF PROPERTY \$ 6.05 (1989).

55. See, e.g., Beam v. Bank of America, 6 Cal. 3d 12, 490 P.2d 257, 98 Cal. Rptr. 137 (1971).

56. But see Marriage of Zells, 572 N.E.2d 944 (Ill. 1991). 


\title{
III
}

\section{ISSUES IN MARKET VALUATION}

\begin{abstract}
A. Market Value as the Ultimate Measure, Whether Direct (Market Sales Price) or Hypothetical (Capitalization of Excess Earnings)
\end{abstract}

Although the various measures of goodwill may be posited as alternative and oppositional, ultimately all measures seek to approximate some version of market value. At divorce, the majority of jurisdictions recognizing nontransferable as well as transferable goodwill "seek to discover what a willing buyer would pay to a willing seller giving no consideration to the impediments of its transfer." 57 Even when a particular variety of goodwill is regularly the subject of market transactions, the price set by the market may understate the value of goodwill in the business spouse's hands. This may occur because only a portion of the goodwill may be expected to survive transfer and because the transferee faces a variety of risks already overcome by the goodwill-developer in his own practice or business. For example, the transferee may not suit the clientele, or the clientele may not suit the transferee. The transferee may have to "learn" the particular business, rendering him initially less efficient than the transferor.

Thus, the existence of a market does not alone indicate or require valuation by market sales pricing at divorce. Nevertheless, it is sometimes suggested, without qualification, that market prices should be used when a business or practice is saleable, and capitalization should be used when it is not saleable. But the goodwill of many practices and small businesses is, effectively, only partially, or fractionally, saleable. ${ }^{58}$ In such cases, in order to approach a true measure of goodwill retained by the developer-spouse, one would have to cumulate the two measures, applying market price to the transferable portion and capitalization to the nontransferable portion.

Alternatively, market sales prices could be adjusted upward to reflect the decline in goodwill value when a business or practice is transferred. This is not, however, generally done in practice. Instead, when market prices do not fully capture the value of goodwill in the developer-spouse's hands, practitioners turn to the capitalization of excess-earnings method, which will be discussed in the next section. This section notes only the extent to which the capitalization method is itself market-based in its most critical calculation, the choice of a capitalization rate to measure, inter alia, the degree of relative risk in the investment. The capitalization rate is established either by direct market comparison or by the summation method, both of which are ultimately marketbased. To the extent we are sensitive to the possibility that market sales pricing may undervalue goodwill that is destined to remain in the developer's hands, so we should also be sensitive to the possibility that market capitalization rates,

57. This formulation was suggested by an attorney at the San Diego goodwill colloquium.

58. Glenn Desmond refers to this portion as the "transferability value." DESMOND, supra note 19, at 4. 
derived as they are from market transfers, may similarly overstate the risks inherent in goodwill retained by its developer.

\section{B. For Divorce Valuation, Market Sales Prices Should Represent a Floor and Capitalization Rates Derived from Market Transactions Should Represent a Ceiling}

Market sales prices should rarely $y^{59}$ be adjusted downward at divorce, and market-derived capitalization rates should rarely ${ }^{60}$ be adjusted upward. To many readers this may seem self-evident. Nevertheless, some commentators effectively suggest that the market may overvalue goodwill for purposes of divorce valuation.

Alan Zipp asserts that market, that is, third-party sale, valuations will not adequately take into account the finite life of goodwill and its depreciation over that finite life ${ }^{61}$ what this article has characterized above as the life and vigor of goodwill. ${ }^{62}$ This is patently implausible. A market purchaser will not be willing to include the value of his own future labor and his new, truly postsale goodwill accumulation in the price he pays the seller. ${ }^{63} \mathrm{He}$ is only willing to pay for the value of the goodwill that both exists at the time of the sale and will survive transfer to him. This value takes into account the estimated life of the presale goodwill and its decline or increase in value over that life. The buyer may be understood to be paying for the already-created business opportunity to develop future (postsale) goodwill, but this opportunity to develop future (postdivorce) goodwill should also be understood as a marital asset to the extent that it inheres in the business at the time of sale or divorce.

This error is repeated in a more subtle way by those who would, in capitalizing excess earnings, first choose a market-based capitalization rate, then apply it to reduce the stream of excess earnings to present value, and then further reduce the present value for the limited life and depreciation of the goodwill. ${ }^{64}$ It is also repeated by those who would choose a market-based capitalization rate and further adjust it upward for the limited life and depreciation of the goodwill. ${ }^{65}$

59. An exception to this general rule might be made for a person who manages his business so inefficiently that it is worth more in terms of future earnings to a buyer than to the inefficient spouse, in which case capitalization of excess earnings would produce a lower figure than market sales pricing.

An exception may also be warranted when a particular type of business is regularly sold at prices that are not economically justifiable in view of the business income stream. In such cases, purchasers effectively are buying a job.

60. An exception must be made for proximate retirement. Because capitalization rates reflect both the risk of realizing future earnings from goodwill and the life of the goodwill, when the developer of nontransferable goodwill is expected to retire before the marital goodwill would otherwise expire, market capitalization rates may overstate the value of that practitioner's goodwill.

61. Alan S. Zipp, Divorce Valuation of Business Interests: A Capitalization of Earnings Approach, 23 FAM. L.Q. 89, 126-27 (1989).

62. See supra text accompanying notes 9-13, 94-105.

63. PRATT, supra note 12 , at $133,165$.

64. Cheatum, supra note 16 , at 47.

65. Jerald Udinsky, supra note 16 , at $37,38-40$. 
To the extent that market experience is the source of capitalization rates, the goodwill market has already adjusted for these factors. The error is confusion of the multifaceted capitalization rate with the interest rate, or risk premium. The latter reflects only risk; the former takes into account all relevant value issues. Thus, to the extent that market sales and market capitalization rates constitute our valuation benchmarks, we should reject general principles and techniques that contemplate value diminution for divorce valuation. ${ }^{66}$

\section{When Market Sales and Capitalization Produce Widely Different Estimates of Value, the Experts Should Be Expected to Explain and Rationalize the Variation}

It is often the case, particularly with professional practices, that the professional spouse's expert proposes a modest sales price estimate of value that is only a small fraction of the capitalization of excess earnings figure proposed by the other spouse's expert. ${ }^{67}$ This wide unexplained variation is often interpreted by judges, litigants, and other relevant players to indicate the unreliability and unsoundness of valuation techniques, the unreliability of "hired gun" experts, the futility of estimating value, and even the illusory nature of the asset in question.

There is usually a much simpler and more benign explanation. The opposing experts are measuring two different assets: the value of the transferable goodwill to a buyer and the value of all the goodwill to the spouse who developed it. The value to the spouse is not in any sense "subjective," as some critics suggest. A professional practice is not the proverbial rocking chair to which one spouse is sentimentally, or subjectively, attached and hence values more highly than does the market. The objective value to the professional spouse is greater than it is to the buyer: The spouse is able to generate greater excess earnings because he will not suffer goodwill loss in transfer and he does not face the other risks and exigencies that confront a purchaser of goodwill. The experts should be expected to shed some light on large variations in valuation. The proponent of the higher value should be prepared to explain why market sales may understate the value of goodwill in the professional spouse's hands.

66. To the extent we use the summation method to construct capitalization rates, however, it may be appropriate to introduce limited life and depreciation into our methodology. The key is the extent to which the factors we use in summation are themselves derived from market sales. When they are so derived, the market has already taken life and depreciation into account. These issues will be fully covered, infra, in the discussion of capitalization methodology.

67. See, e.g., Marriage of Fortier, 34 Cal. App. 3d 384, 109 Cal. Rptr. 915 (1973). 


\section{The Excess-Earnings Measure of Traditional Professional and COMMERCIAL GOODWILL}

\section{A. Introduction}

The excess-earnings measure purports to isolate the value of goodwill by a process of exclusion. It calculates net earnings and then reduces net earnings by the sum of the market value of the manager's or professional's labor, a reasonable return on the tangible assets, and, if applicable, a reasonable return on any separately ascertainable and quantifiable intangible assets. ${ }^{68}$ Remaining excess earnings are attributed to goodwill. Once the excess-earnings stream is identified, it is reduced to present value. ${ }^{69}$

Goodwill is thus a residual value, whose existence and value are established by otherwise unexplained income. Although the specific methodology used at divorce seems to have been derived from a 1968 Internal Revenue Ruling, ${ }^{70}$ excess-earnings formulations are widely used by accountants to value businesses and practices for prospective purchasers. The specific methodology derived from Revenue Ruling 68-609 is specially responsive to the allocation issues presented by marital property distribution at divorce. Its carefully focused attention on the value of the professional's labor enables the necessary allocation between return on postdivorce labor, which is the separate property of the laborer, and return on marital goodwill.

\section{B. The Excess-Earnings Base}

1. Looking Backward to Project the Future. The ultimate goal is identification of the stream of postdivorce earnings attributable to accumulations of marital goodwill. Nevertheless, with owner-developed goodwill, we typically look to the five-year period before divorce. There are sound reasons for this practice, although some adjustments may be indicated. Examination of a five-year period helps to insure that earnings are representative and not aberrant. Averaging is appropriate when earnings rise and fall over the five-year period. When, however, a steady upward or downward trend is evident, averaging will not assist an accurate prediction of future earnings.

It may seem odd, on first impression, that we restrict our vision to the past when attempting to predict the future, and all the more odd when that future is already upon us. ${ }^{71}$ There is, nevertheless, a compelling justification for this

68. E.g., patents, copyrights, valuable long-term leases.

69. For a generally lucid case law account, see Dugan v. Dugan, 457 A.2d 1, 9 (N.J. 1983).

70. Rev. Rul. 68-609, 1968-2 C.B. 327.

71. In some states, the marital economic community ends at permanent physical separation or the filing of the divorce complaint. See supra note 41 . In such jurisdictions, at divorce we may be valuing marital goodwill several years after the marital economic community has come to an end, but we nevertheless confine our inquiry to the marital period, ignoring already-realized, higher postmarital 
backward-looking practice. Postdivorce excess earnings are likely to reflect postdivorce accumulations of goodwill, which are the practitioner's separate property. If we were to consider postdivorce excess earnings, we would have to allocate between return on marital goodwill and return on postdivorce goodwill. In order to accomplish this allocation, we would probably calculate the difference between postdivorce and marital earnings and characterize the difference as the earner's separate property. We short-circuit this unnecessary step by restricting ourselves to consideration of marital excess earnings.

Commentators often express strong dissatisfaction with appellate language that may be read to misunderstand and confuse the issues in goodwill valuation. ${ }^{72}$ Courts frequently insist that, at divorce, we are to measure some past accomplishment and not the future earnings of a spouse. To the extent this language may be understood to reject the principle that the present value of goodwill, like the present value of any asset, is its capacity to generate future income, this language is clearly incorrect. On the other hand, this ambiguous language may be understood to articulate a correct and much narrower principle: Postdivorce earnings are likely to reflect postdivorce goodwill accumulation, and hence we should confine our inquiry to the period during which excess earnings are generated entirely by marital imputs. ${ }^{73}$

Some may perceive an incoherence in our insistence on looking backward to estimate future excess earnings and our willingness to look forward to determine the likelihood that these earnings will continue in the future. For example, if a professional is nearing retirement and his goodwill is nontransferable, we necessarily look forward when we appropriately assign the goodwill a short life. Yet these two positions are consistent. We do not look forward to determine the amount of excess earnings in order to avoid confusing marital and postdivorce goodwill. But there is no general prohibition against looking forward, and there is nothing objectionable about doing so to estimate the probable life of marital goodwill.

\section{In Projecting Future Earnings Attributable to Marital Goodwill, Should Past} Excess Earnings Be Adjusted for Inflation and Real Growth? We expect that excess earnings attributable to marital goodwill will grow with inflation. This is not real growth but is simply a nominal increase that results from decline in the value of the dollar. Excess earnings may also experience real growth if, for example, a rise in professional fees outstrips inflation, or an increase in demand

excess earnings. See infra cases cited in note 73.

72. See, e.g., Udinsky, supra note 16, at 38.

73. In context, the language of Foster and Slater is susceptible to such a reading. Marriage of Foster, 42 Cal. App. 3d 577, 117 Cal. Rptr. 49 (1974); Marriage of Slater, 100 Cal. App. 3d 241, 160 Cal. Rptr. 686 (1979).

The preference for examining past rather than future earnings is also evidenced in market pricing behavior. Shannon Pratt explains: "Another reason why the [discounted future earnings] method is not used more in small businesses and professional practices is that . . buyers are naturally reluctant to include in the present value any future benefits that really depend on their own efforts rather than ... resulting from forces already in place." PRATT, supra note 12, at 165 . 
for services enhances the value of already-existing goodwill. Generally, it should be unnecessary to adjust the stream of excess earnings to account for nominal or real growth. When capitalization rates are based upon market sales of transferable goodwill, nominal and real growth should already be reflected in the market capitalization rates. ${ }^{74}$

\section{How Do We Determine the Value of the Professional Spouse's Labor? The} case law and commentary responses to this question vary substantially. Often this variation goes unrecognized or unacknowledged. In principle, at least, there is a clear answer to this question. The value of the practitioner spouse's labor is the price that the market would set, assuming that the spouse brings no tangible or intangible business assets to the new job. ${ }^{75}$ We assume, however, that the practitioner spouse brings all his human capital, that is, his education, his experience, and his skill (as opposed to his local reputation for skill) to the job. And, importantly, we must control for hours worked. Californians might think of our construct as "Dr. Chicago." Dr. Chicago comes to California with all his credentials and experience, and allows the market to bid for his services. In principle, it should not be difficult to ascertain the market value of Dr. Chicago's services. We could present his vitae to several headhunters and HMOs, and solicit a salary estimate, controlling for hours worked.

A subtle point should be noted. There is a direct relationship between a professional's opportunity to practice his profession independently of any employer and the market price that employers must pay for his services. Each is the opportunity cost of the other. Hence the "market value of a professional's labor" is itself a function of his capacity to generate practice goodwill. The physician's salary contains compensation for labor and for his lost opportunity to accumulate practice goodwill. To value his labor alone, we might consider what he would earn in a line of work entailing similar education, training, intelligence, experience, and responsibility, but that would not offer the same entrepreneurial possibilities as do the liberal professions. From this vantage point, measurement based on comparable salary for professional workers may overstate the value of labor vis-à-vis goodwill. Nevertheless, our current

74. If we derive our capitalization rate by the less desirable summation method, discussed in text infra at notes 87-91, it is still unnecessary to adjust the stream of excess earnings to account for nominal or real growth. Both can be accounted for by adjusting the capitalization rate.

If we begin our summation analysis by examining expected returns on risk-free, interest-bearing instruments, which often form the base for both market and summation capitalization rates, we will want to take inflation into account. Rather than do this by projecting inflation forward over the life of the goodwill, a simple way to reach the same result is to reduce the capitalization rate by the annual inflation rate. What we are doing, effectively, is constructing an inflation-free calculus to control for future inflation. If, for example, the real interest rate is 3 percent and the inflation rate is five percent, we should expect a nominal interest rate of eight percent for risk-free instruments. If we wish to purchase a risk-free stream of income that will itself experience normal inflationary growth, we should apply a discount rate of three percent, not eight percent.

75. This qualification is important because an HMO or DMO employer in the same locality may be effectively purchasing a local practitioner's goodwill when it hires him at an enhanced salary.

76. This construct was suggested by a San Diego attorney. 
approach is the best we can do in a marital property system that generally treats a spouse's professional credentials as his separate property: ${ }^{77}$ The capacity to command a high salary in the market, whatever its mediate causes, inheres in the possession of professional credentials. To the extent we generally treat postdivorce salary as entirely the earner's separate property, we are bound to use it as the base in goodwill measurement as well.

Although most commentators frame the inquiry in terms of market salaries, some express positions or conclusions that are, explicitly or implicitly, inconsistent with this approach. Some understand "excess" to refer to earnings in excess of those earned by the average professional, or by the average professional in private practice. This approach would determine whether a professional has above-average earnings; it does not measure his goodwill. Presumably, most ${ }^{78}$ practitioners who persist in private practice are successful in achieving excess earnings; otherwise they would give up practice and accept salaried jobs. Thus, in comparing private practitioners, this approach may merely identify aboveaverage goodwill. The essential shortcoming of this average-earnings formulation is that it does not attempt to make the necessary distinction between returns on separate labor and human capital, on the one hand, and marital goodwill, on the other.

Some commentators who use such average-earnings formulations are understandably concerned about the conceptual incoherence of their position and the difficulty of developing adequate data. The ambiguity of the term "average" further confuses the task. To pursue this approach, one would presumably use average earnings data from the locality. But someone with above-average earnings may well be above-average in some way we associate with his separate property human capital endowment, for example, intelligence, quality of education, and experience. And average-earnings data does not control for most of these variables. Thus, a highly trained and specialized physician might have above-average earnings compared to other practitioners in the locality yet have no goodwill at all in the sense that he could earn more by selling his services in the labor market. These problems evaporate, however, when we rigorously apply the correct test, which focuses on the value of this particular practitioner's labor, taking into account all the human capital aspects that make his labor valuable and controlling for the number of hours worked.

Nevertheless, some northern California practitioners report that they historically had difficulty developing adequate data for the correct test and thus came to rely, for lack of anything better, on "average earnings of private practitioners."

77. See generally Blumberg, supra note 44, \& 23.06. New York and Michigan are notable exceptions to this general rule. Appellate courts in both states have characterized maritally acquired professional education as marital property. O'Brien v. O'Brien, 489 N.E.2d 712 (N.Y. 1985); Postema v. Postema, 471 N.W.2d 912 (Mich. Ct. App. 1991); Wiand v. Wiand, 443 N.W.2d 464 (Mich. Ct. App. 1989).

78. I say most because some practitioners may value autonomy and independence more than dollar income.

79. Letter from a northern California attorney (retained by the author). 
ners were self-employed, either individually or in professional partnerships, and that there was limited labor market salary data with which to value their labor. Today, however, members of the liberal professions frequently work for salaries in, for example, health maintenance organizations, and industrial and commercial corporations. Moreover, there are now employment agencies that specialize in professional and executive placement. Thus, it should now generally be possible to develop the data necessary to apply the correct excess-earnings test.

\section{Capitalization Rates: A Contested Ground}

An understanding of the nature of capitalization rates and the selection of the applicable rate for a given situation is probably the most difficult problem in the entire process of business valuation .... ${ }^{80}$

"It's all in the cap rate."

1. Introduction. Capitalization is the process of reducing a stream of future income to present value. If the stream is expected to be perpetual, the capitalization rate is the expected rate of return ${ }^{82}$ on similarly risky investments. If the anticipated stream is finite, the capitalization rate is the sum of the interest rate and the capital recovery rate. ${ }^{83}$ There are two basic methods for developing capitalization rates. The first is direct market comparison. The second is the summation method. Each should be specially tailored for use in divorce valuation.

2. Direct Market Comparison. In direct market comparison, we seek market sales of similar businesses or practices with largely transferable goodwill, and we infer capitalization rates from their sales prices. How we define the income stream is not as critical as consistency of definition. In order to avoid comparing incomparables, it is vital that we use the same definition of earnings in comparison cases or that we make appropriate capitalization rate adjustments to reflect differences in income stream definition.

Capitalization rates inferred from direct market transfers will already have accounted for risk, illiquidity, and the finite life and depreciation of assets. Market-derived capitalization rates should be further increased to reflect these factors only when, for special reasons, they are different in the spouse's business or practice than in the businesses or practices observed in comparison market sales.

In most professional practices and some small businesses, capitalization rates derived from direct market transfers are likely to understate the value of the

80. PRATT, supra note 12, at 122.

81. Attorney, San Diego goodwill colloquium.

82. I use the term "return" broadly to include both future earnings and future earnings growth nominal and real, that derive from marital goodwill. For further discussion, see the summation method of setting capitalization rates infra text accompanying notes 84-85.

83. These principles are developed and illustrated in the introductory section of this article. 
goodwill in the hands of the spouse who developed it. Thus, capitalization rates from market transfers should generally be adjusted downward.

Much professional goodwill is predicated upon client trust. Once trust is established, the professional-client relationship is relatively immune to price competition. This occurs because patients and clients generally consider themselves unable to evaluate the quality of a professional's expert services. ${ }^{84}$ Even under optimal conditions, with careful planning and cooperation between buyer and seller, only a portion of this goodwill, that is, only a portion of the capacity to generate past excess earnings, can be transferred to the buyer. ${ }^{85}$ Thus, the risk factor for goodwill loss-in-transfer, which is included within capitalization rates inferred from direct market transfers, should be eliminated for purposes of divorce valuation. ${ }^{86}$

Some portion of a direct market transaction capitalization rate reflects a discount for illiquidity. Liquidity is, of course, always preferable to illiquidity, but the buyer of a business or practice has greater concerns about illiquidity than does the person who developed the practice and who plans to continue in it. A purchaser may find that the nature of the business, the clientele, or the locale does not suit him, or that he does not suit the clientele. These possibilities do not represent uncertainties for the divorcing spouse who developed the business. When a divorced spouse is going to retain his owner-managed business or practice, the capitalization rate should be reduced to reflect the lesser significance, or risk, of illiquidity for him.

Even under optimal circumstances, the buyer is unlikely to realize the seller's excess-earnings stream because the buyer must learn a new business or practice. Some inefficiency, some slip-ups, and some false starts will surely occur, and the buyer discounts accordingly. These risks are not faced by the divorcing spouse, and discounts for them should be removed from the capitalization rate.

In summary, the established owner of a small business or professional practice experiences some of the risks that a prospective buyer would face. They both are subject to risk factors arising from general economic conditions and generally attaching to the line of business or profession. But they do not equally face risks pertaining to the particular practice, especially risks relating to client loyalty, illiquidity, and knowledge, or lack thereof, of the practice. In a sense, the seller's risks are embodied in his prior five-year earning stream, which reflects his capacity to retain clients, the vicissitudes of the local and national economy, and the state of his line of business or profession. The only additional

84. PRATT, supra note 12 , at 293.

85. Id. at 292. See also DESMOND, supra note 19, at 39.

86. Technically, predicted loss in direct market transfers of goodwill could be handled in a number of ways. Excess earnings could be reduced to those expected to survive transfer and then that lossreduced amount would be capitalized at a relatively low capitalization rate. Or past excess earnings could be left unadjusted and the risk of loss-in-transfer reflected in a relatively high capitalization rate. The latter possibility seems to describe current practice in valuing businesses for sales purposes. In divorce valuation, the capitalization rate should thus be reduced to eliminate the risk of goodwill loss-intransfer. 
risk he faces is: Will he be able to perform in his business or practice as well as he did in the past? For the purchaser the question is: To what extent will he be able to approach the excess earnings of the seller? These questions should be expected to yield quite different capitalization rates for the market purchaser and for the divorcing practitioner-spouse, who is effectively purchasing his spouse's share of the goodwill that he has developed.

\section{Developing a Capitalization Rate by the Summation Method. The} summation method identifies and assigns a rate to each of the various risk factors, and then sums the rates. ${ }^{87}$ Its conceptual strength is that it invites consideration of all relevant factors. Its weakness lies in its assignment of values to each risk factor. Because there is little empirical data, quantification is largely subjective. $^{88}$ Additionally, some commentators show a tendency to doublecount risk factors, ${ }^{89}$ which results in implausibly and unjustifiably high capitalization rates. These shortcomings suggest that the summation method be treated as a back-up method, used only when market sales of goodwill provide inadequate guidance. Nevertheless, examination of the method is a useful exercise because it furthers understanding of basic goodwill measurement issues.

The summation method begins with a benchmark rate for risk-free obligations, such as treasury bill or long-term government bond rates. Then it locates another somewhat riskier form of investment, but one that most would agree is less risky than the business or practice goodwill to be valued. It adds the difference between the return on this investment and the return on the riskfree obligation. ${ }^{90}$ Next, the method requires that additional risk factors, including illiquidity, be identified and quantified. Then the rates are summed..$^{91}$

87. For a lucid treatment, see PRATT, supra note 12, at 122-42.

88. Id. at 136.

89. See, e.g., Zipp, supra note 61 , at $125-26$.

90. Until this point, the method is unquestionable, so long as the benchmarks are unchallenged, which should usually be the case.

91. DESMOND, supra note 19, at 49. At this juncture, negative correction must be made for expected earning growth due to known factors. PRATT, supra note 12, at 132-33,147. Such growth may be merely inflationary (nominal), e.g., five percent, or may be real, due to factors such as expected population increase in the business or practice locale. This adjustment must be made because, conceptually, the rate of return includes both expected earnings and expected growth rate (capital appreciation). (Thus, investors will accept lower earnings from assets that promise higher capital appreciation, such as real estate.)

Moreover, the adjustment is technically required because the no-risk benchmark used in the summation method is a return on an interest-bearing instrument. If, for example, a T-bill or long-term government bond is yielding eight percent annual interest, the eight percent includes three percent for real interest and five percent for inflation. If the excess earnings attributable to marital goodwill are expected to keep up with inflation, this five percent must be deducted. The five percent would not be required by an investor in goodwill because the inflationary five percent will be reflected in inflationadjusted future earnings. If inflation is the only increase currently anticipated in future earnings, the adjustment can be made by simply using the real (three percent) rather than the nominal (eight percent) interest rate as the benchmark base for summation. If, however, real increase is also anticipated, the calculation is best done separately after risks have been summed. The expected earnings rate less the expected growth rate is the discount rate. For a perpetuity or an asset with a long life (15 years or more), the discount rate is the capitalization rate. If the estimated life of the marital goodwill is, however, considerably shorter, the discount rate should be further increased by a capital recovery rate. 
4. Prevailing Capitalization Rates. The literature abounds with estimates of appropriate capitalization rates. It is often unclear how they have been derived, although there seems to be a consensus, however reached. Shannon Pratt reports:

The consensus among participants in the marketplace (buyers and sellers, brokers, appraisers, and others) seems to be that the required total rate of return on an equity investment in a small business is in the range of 20 to 40 percent; this depends on the degree of risk, and is higher for unusually risky situations.

With reference to professional practices, Pratt observes " $[t]$ he return expected on the professional practice's net asset value should be neither more nor less than any other small business would expect to receive. ... Capitalization rates for the professional's excess earnings [pretax earnings after owner compensation] range from 20 to 100 percent." 93

The rate used in Revenue Ruling 68-609, adjusted for current inflation, is consistent with such estimates. Published in 1968, it proposed fifteen to twenty percent as a reasonable return on excess earnings but noted that "[t]he percentage of return should be the percentage prevailing in the industry involved on the date of valuation." In 1968, the average yield on long-term government bonds, a risk-free benchmark for the summation method of developing capitalization rates was five percent. In 1992, it was eight percent. Adding three percent to the required return on intangibles would yield a capitalization rate of eighteen to twenty-three percent for the Revenue Ruling formula, which is on the low end of market-based estimates. ${ }^{94}$

All of the above estimates are intended largely for counseling buyers and sellers contemplating market transactions, or for establishing business value for gift and estate taxation. These estimates contemplate a transfer and do not purport to value the business in the goodwill developer's hands. Thus, these estimates of prevailing capitalization rates are likely to overstate risk in ownerretained businesses and practices. Nevertheless, the whole range should probably not be shifted downward. Given current rates of return for alternative investments, twenty percent would seem a minimum capitalization rate for small business investments. The adjustment should probably come, instead, in recognizing that risk increments to the twenty percent should be discounted for owner retention; absent extraordinary risk, owner-retained businesses and

PRATT, supra note 12 , at 4-7.

92. PRATT, supra note 12, at 142.

93. Id. at $307-08$. Desmond reports that he generally applies a $20 \%$ capitalization rate to excess after tax earnings. DESMOND, supra note 19 . See also id. at 49 , where the author illustratively develops a $20 \%$ rate by the summation method.

94. See Pratt, supra note 12 , at 163 . When Pratt wrote in 1986 , the benchmark long-term government bond rate was $12 \%$, further increasing the formula's reasonable rate of return. 
practices should be capitalized in, for example, the twenty to thirty-five percent range.

\section{Other Discount Factors: Depreciation and Taxation}

1. Introduction. I have already emphasized that market-derived capitalization rates necessarily reflect the life and vigor of an asset, as well as the taxability of future income streams. Nevertheless, both issues arise frequently and deserve some discussion, if only because the belief that they pose real problems may encourage and justify the use of unwarrantedly high capitalization rates.

\section{Depreciation.}

a. How we understand it. There seems a wide range in perception about the life and vigor of maritally developed goodwill. Some see it as existing for the life of the business or practice, as "positioning" a spouse for continued excess earnings. Others see it as short-lived and rapidly depreciating. Some of this variation may be based on differences in personal professional experience, but a good deal seemed to arise from differing accounts of the same phenomena.

One commentator has analogized goodwill to a house plant and suggested that, at separation, we treat the marital goodwill as a plant that is no longer watered..$^{95}$ Another suggests: "After separation, we create a model wherein the . . . community goodwill asset depreciates to zero, because no future effort is being made to maintain it. Thus, the enhancement of the in-business spouse's earnings will diminish to zero." $\%$ If we were to accept these descriptions as factually correct or as legally required, we would be obliged to conclude that maritally developed goodwill has no cognizable value at all. At the point of marital dissolution, if no future effort will be made to maintain the goodwill, it has zero value now. But the law assumes that there will be no waste, that appropriate efforts will be made out of future separate labor or income to maintain maritally developed assets. This is not peculiar to goodwill. When we value the family home or a marital property automobile, we do not discount it on the assumption that no future effort will be made to maintain it. We assume instead that the asset will be properly maintained.

It is important to distinguish between goodwill creation and goodwill maintenance, between establishing a successful practice and maintaining a successful practice. Maintenance after divorce must be counted as the practitioner's separate labor, but that maintenance does not diminish or supplant the value of the marital goodwill. Assume, for example, that during marriage a surgeon has cultivated a number of referring physicians, and has developed a community reputation for surgical skill and patient satisfaction. To maintain and exploit this goodwill after divorce, he must continue (1) to practice skillfully, (2)

95. Cheatum, supra note 16 , at 47.

96. Udinsky, supra note 16 , at 37 . 
to satisfy patients, and (3) neither to offend nor lose touch with the referring physicians. The first two activities are normally included in any appropriate accounting of separate property labor used in an excess-earnings formulation; the third may require some small additional effort or may be simply incidental to the first two. Thus, the continued postdivorce presence of the spouse in the business or practice should not alone be understood to diminish the life or vigor of marital goodwill.

b. The life of goodwill. Most commentators agree that the life of goodwill is finite and indeterminate. ${ }^{97}$ As demonstrated in the introduction, we need only be concerned about the finiteness of goodwill if we are not using capitalization rates derived from market sales (which will already have considered the estimated life of the asset) and if we estimate a relatively short life. If we estimate fifteen or more years, as a practical matter, we may as well assume a perpetuity. ${ }^{98}$

Given the indeterminate life of goodwill, careful commentators are generally unwilling to estimate its duration. Catlett and Olson suggest that if purchased goodwill is to be amortized, "[a] suitable maximum term would be [twenty] years, which is in line with the multiples used in the more conservative capitalizations of income." $" 99$

c. The vigor of goodwill. Several commentators have suggested depreciation schedules for goodwill. ${ }^{100}$ There is a certain plausibility in this suggestion because we are accustomed to depreciating tangible assets to zero value. Nevertheless, depreciation is not necessarily appropriate for goodwill, which is not consumed in production and does not experience physical deterioration, as do tangible assets. It is true, of course, that some clients may die, move away, or otherwise desert a practitioner. ${ }^{101}$ Yet equally plausibly, one might propose an appreciation schedule. For example, an internist's currently satisfied patients have friends and relatives whom, without further effort of the internist, they will refer to his practice in future years, and those new patients will refer yet another set of new patients. Goodwill snowballs and all of these patients are traceable to marital goodwill, without which they would not have been referred. It is true that there will also be imputs of postdivorce goodwill and that marital and

97. "Goodwill value is not consumed or used in the production of earnings as are the separable resources and property rights of a business. Changes in the value of goodwill cannot . . be assigned to a period on a rational or systematic basis .... The value of goodwill may, and does, fluctuate suddenly and widely because of the innumerable factors-factors affecting earning power-which influence that value. Goodwill value may rise, fall, expire, and be recreated by those factors many times and in unpredictable ways during the life of a business .... A careful consideration of these characteristics of goodwill indicates that goodwill cannot be evaluated in terms of either an unlimited life or a measurable estimated limited life." CATLETT \& OLSON, supra note 9, at 85. See also sources cited supra note 11.

98. See supra text accompanying notes $20-21$.

99. CATLETT \& OLSON, supra note 9, at 142.

100. See, e.g., Udinsky, supra note 16, at 38-40; Cheatum, supra note 16, at 47.

101. See generally Reppy, supra note 16 , at $187-88$. 
postdivorce goodwill may combine synergistically, but this does not necessarily mean that marital goodwill has declined in absolute value or has become valueless.

Proposals for goodwill depreciation schedules tend to assume that there is a constant amount of goodwill and that, therefore, postdivorce acquisitions of goodwill must be replacing marital goodwill. ${ }^{102}$ For successful businesses and practices, however, stores of goodwill may be increasing constantly. This is obviously the case in an ever-expanding commercial business. Even in a professional practice, the successful practitioner may respond to increasing clientele by hiring subordinate workers or by limiting his practice but charging higher fees and selecting only the most desirable clients or patients.

It would seem questionable, therefore, whether there is any sound basis for general $^{103}$ depreciation theories at divorce valuation of professional and commercial goodwill. If you still find yourself unpersuaded and believe, at least for the professional, "that you are only as good as your last performance,"104 consider the following hypothetical. Dr. John Fliss, a highly successful orthodontist, began his practice in 1968. By 1989, when he decided to settle down and marry Barbara Bellefleur, he had a paraprofessional and clerical staff of seven employees and was netting $\$ 150,000$ annual excess earnings. In 1993, when Barbara left and sued him for divorce, John was netting $\$ 200,000$ annual excess earnings. Barbara claims that $100 \%$ of the goodwill is marital property because "you are only as good as your last performance," and because orthodontic patients complete their course of treatment in fewer than four years. ${ }^{105}$ If you do not agree with Barbara, you should have some difficulty with the short-life and depreciation theories proposed by some commentators.

In any event, and most importantly, the use of market-derived capitalization rates should obviate the need for depreciation schedules because the capitalization rates themselves reflect the market's estimate of the life and vigor of the goodwill.

3. Taxation. Some commentators express concern about the practice of capitalizing excess earnings that are not reduced by the personal income taxes that will be imposed upon those earnings. Some explain the use of otherwise

102. See, e.g., Udinsky, supra note 16 , at 40.

103. If, of course, a spouse is approaching retirement age and is expected to retire, the life of nontransferable goodwill is clearly limited and should be valued accordingly. This is, however, a special case.

104. This observation may be understood to confuse goodwill maintenance with goodwill creation. To demonstrate this proposition factually, one would have to show a practice whose client list after divorce bore no relationship to the client list at divorce, and was in no way generated by the reputation or referral sources existing during marriage or derivative therefrom. This seems an implausible claim.

The "only as good as your last performance" perspective may also be understood to evidence a good deal of anxiety. See supra note 8.

105. In fact, an attorney-participant in the California Judicial Council goodwill colloquia observed that the claim I ascribe to Barbara generally does not arise in practice because persons who marry professionals with thriving practices recognize the continuing importance of premarital stores of goodwill, and hence do not make significant goodwill claims when divorce terminates a relatively short marriage. 
unwarrantedly high capitalization rates as a sub silentio response to this perceived problem. ${ }^{106}$ Although this article has explained why current practice is correct, ${ }^{107}$ it probably warrants further discussion in this section on capitalization.

Most assets generate taxable income. Those that generate nontaxable income, for example, municipal bonds, are capitalized at commensurately lower rates. At current maximum federal-state marginal rates of, say forty percent, if risk-free long-term bank certificates of deposit yield eight percent taxable interest, investors will expect municipal bonds to yield at least $4.8 \%$ nontaxable interest. The capitalization rates we apply to excess earnings are based upon the opportunity cost of purchasing comparable assets that also yield taxable income. The only tax problem we encounter with goodwill distribution at divorce is the pervasive issue of basis inequality. This problem is not peculiar to goodwill, and it attains economically significant dimensions only when we posit (probably unjustifiably) a very short life for goodwill. ${ }^{108}$

Because the taxation misunderstanding seems so widespread, I will take yet another pass at it from a slightly different perspective. The misunderstanding may arise from a confusion between the present value of a stream of future earnings and the stream of future earnings itself. If a court were to order a waitand-see distribution, that is, a split of excess earnings when and if received, then when those earnings are received and split, the tax consequences must be equally shared by both parties. In such case, we would reduce the income by its federal and state income tax before distributing the after-tax remainder to the spouses. Yet for purposes of tax accountability, the present value of the future stream is not a proxy for the future stream. The present value represents the amount which, if invested at the discount rate, will produce the future stream. Investment of the present value amount will generate taxable income so that both spouses will be more or less equally situated taxwise with respect to relatively long-lived assets. Neither will realize full excess earnings; each will receive tax-reduced income.

\section{E. Double-Dipping}

Many courts and commentators ${ }^{109}$ express concern about the potential for double-dipping, that is, assigning the goodwill at divorce to the business or

106. At the San Diego colloquium on October 6, 1990, a California Superior Court judge commented, "Frankly, judges use a conservative approach [to goodwill valuation] to compensate for not taking taxes into account and [for not taking into account the possibility of] double-dipping." Doubledipping is discussed infra text accompanying notes 109-42

107. See supra text accompanying notes $27-32$.

108. Id.

109. See, e.g., Double-Dipping, 7 Equitable Distribution J. 73 (1990); Jill Adams, Note, Community Property, Valuation of Professional Goodwill, 11 N.M. L. REV. 435, 445 (1981); George N. Norton, Professional Goodwill-Its Value in California Marital Dissolution Cases, 3 CommUNITY PROP. J. 9, 17-18 (1976); Stuart B. Walzer, Divorce and the Professional Man, 4 FAM. L.Q. 363, 368 (1970). 
professional spouse, and then taking into account postdivorce realization of excess earnings for the purpose of determining his spousal support obligation. ${ }^{110}$ Although California case law sanctions this practice, ${ }^{111}$ many California practitioners and judges believe it to be incorrect and unfair to the payor spouse. ${ }^{112}$ Some suggest that the possibility of double-dipping encourages the use of unwarrantedly high capitalization rates as a sub silentio antidote. ${ }^{113}$ While some states agree with California case law, ${ }^{114}$ in other states, courts ${ }^{115}$ and even legislatures ${ }^{116}$ have been more responsive to the double-dipping claim: Some courts have simply avoided twice tapping what they perceive as the "same source"; 117 others have declined to recognize professional goodwill as a distributable marital asset on the theory that income from such goodwill is

110. At the California goodwill colloquia, some California practitioners assert that there is also a "triple" dip for child support. The text discussion examines only the more frequently made claim that property division and spousal support improperly look to the same income twice.

111. Marriage of White, 192 Cal. App.3d 1022, 237 Cal. Rptr. 764, 767 (1987) (although community pension awarded to husband at divorce, husband's later receipt of benefits from pension should be included within his income available to pay spousal support); Marriage of Epstein, 24 Cal. 3d 76, 91 n.4, 154 Cal. Rptr. 413, 592 P.2d 1165, 1174 n.4 (1979) (dictum).

112. This opinion was frequently expressed at the California Judicial Council goodwill colloquia.

113. See supra the Superior Court judge's comment in note 106.

114. See, e.g., Kentucky: Clark v. Clark, 782 S.W.2d 56, 62 (Ky. Ct. App. 1990) (professional goodwill); Maryland: Riley v. Riley, 571 A.2d 1261, 1264 (Md. Ct. Spec. App. 1990) (pension); Michigan: Kowalesky v. Kowalesky, 384 N.W.2d 112, 116 (Mich. Ct. App. 1986); Nebraska: Raley v. Raley, 357 N.W.2d 470 (Neb. 1984) (pension); North Dakota: Fraase v. Fraase, 315 N.W. 2d 271, 275 (N.D. 1982) (law firm interest); Oklahoma: Carpenter v. Carpenter, 657 P.2d 646, 651 (Okla. 1983) (pension); Ohio: Kahn v. Kahn, 536 N.E.2d 678, 681-82 (Ohio Ct. App. 1987) (professional goodwill); Oregon: Baumgartner v. Baumgartner, 770 P.2d 965 (Or. Ct. App. 1989) (professional goodwill); Goebel v. Goebel, 641 P.2d 59, 61 (Or. Ct. App. 1982) (professional corporation); Pennsylvania: McFadden v. McFadden, 563 A.2d 180, 184 (Pa. Super. Ct. 1989) (pension); South Dakota: Gibson v. Gibson, 437 N.W.2d 170, 172 (S.D. 1989) (pension).

115. See, e.g., Florida: Waldman v. Waldman, 520 So.2d 87, 90-91 (Fla. Dist. Ct. App. 1988) (pension); Michigan: Walker v. Walker, 399 N.W.2d 541, 542 (Mich. Ct. App. 1986) (since plaintiff consented at divorce to defendant's receipt of pension benefits as property, "defendant's pension cannot now be recategorized as income in determining his ability to pay alimony"); but see Lang v. Lang, 425 N.W.2d 800, 802 (Mich. Ct. App. 1988) (court may divide value of retirement plan at divorce and consider income from retirement plan in determining alimony award); Minnesota: Kruschel v. Kruschel, 419 N.W.2d 119, 122 (Minn. Ct. App. 1988) (pension); Missouri: Balven v. Balven, 734 S.W.2d 909, 913 (Mo. Ct. App. 1987) (retirement bonus); South Dakota: Stemper v. Stemper, 403 N.W.2d 405, 408, modified on other grounds, 415 N.W.2d 159 (S.D. 1987) (pension); but see Gibson v. Gibson, 437 N.W.2d 170, 172 (S.D. 1989) (pension); Wisconsin: Holbrook v. Holbrook, 309 N.W.2d 343, 355 (Wis. Ct. App. 1981) (goodwill); but see Peerenboom v. Peerenboom, 433 N.W.2d 282, 284 (Wis. Ct. App. 1988) (If goodwill is established as a "separate asset," all future earnings may be considered for purposes of support) (dictum); Johnson v. Johnson, 254 N.W.2d 198, 201-02 (Wis. 1977) (accounts receivable); Overson v. Overson, 370 N.W.2d 796, 799 (Wis. Ct. App. 1985) (income-producing real estate holdings).

116. See, e.g., N.J. STAT. ANN. \& 2A:34-23 (West Supp. 1992).

117. See, e.g., Marriage of Hogeland, 448 N.W.2d 678, 681 (Iowa Ct. App. 1989) (since the court considered goodwill in determining alimony award, it should not also consider it in valuing the corporation's stock); Walker v. Walker, 399 N.W.2d 541, 542 (Mich. Ct. App. 1986) (pension award to defendant in property division precluded tapping pension again to determine alimony); D'Oro v. D'Oro, 454 A.2d 915, 916 (N.J. Super. Ct. Ch. Div. 1982) (once pension is distributed in property division, the court cannot tap pension again to determine alimony), affd, 474 A.2d 107 (N.J. Super. Ct. App. Div. 1984); Pelot v. Pelot, 342 N.W.2d 64, 66 (Wis. Ct. App. 1983) (pension). 
available for spousal and child support. ${ }^{118}$ This section shall address three discrete questions. Is there double-dipping? In other words, is there a single asset that is tapped twice for property division and spousal support? If so, is the double-dip objectionable? If it is objectionable, how should it be cured?

1. Is there Double-Dipping? To most observers it seems self-evident that the same asset is tapped twice when goodwill is "purchased" by the originator-spouse at a divorce "sale," and all future earnings are then included in the spouse's income for the purpose of determining his support obligations. Nevertheless, it may be argued that this is an erroneous perception, that the present value of future excess earnings should, for this purpose, be treated as different from the excess earnings when and if received. ${ }^{119}$ Although I make a similar point above on the issue of taxation, I initially had difficulty with this argument insofar as it pertains simply to realization of the value of goodwill. It seemed to me that the only way that a business or professional spouse who persists in his business or practice will realize the value of his marital goodwill-whether or not that goodwill is marketable - is in the receipt of postdivorce business earnings. To say that he owns two different assets, the present value of his goodwill and the excess earnings as they are realized, seemed to misdescribe reality. Yet as I worked my way through the issues, this argument began to seem more plausible. I will return to it in the remedies section. ${ }^{120}$

2. Is Double-Dipping Problematic? Assuming, for the purposes of discussion, that the same asset is tapped twice when goodwill is valued at divorce and all postdivorce earnings are deemed available for support, case law ${ }^{121}$ and commentary ${ }^{122}$ divide on whether such double-dipping is problematic and should be avoided. There are at least three reasons why some who acknowledge that there is double-dipping nevertheless perceive it as unobjectionable.

The first justification is that the income source is applied for two different purposes. The first tap occurs as a property distribution. The second occurs as

118. Illinois: Marriage of Zells, 572 N.E.2d 944, 945-46 (Ill. 1991); Oklahoma: Travis v. Travis, 795 P.2d 96, 99 (Okla. 1990); Wisconsin: Holbrook v. Holbrook, 309 N.W.2d 343, 355 (Wis. Ct. App. 1981); but see Peerenboom v. Peerenboom, 433 N.W.2d 282, 284 (Wis. Ct. App. 1988); see also Johnson v. Johnson, 254 N.W.2d 198, 201-02 (Wis. 1977) (accounts receivable not marital property because would be available, when received, as the basis for alimony); accord Dogu v. Dogu, 652 P.2d 1308, 1310 (Utah 1982).

119. This position was taken by an attorney at the Los Angeles colloquium. For similar analysis, see Marriage of White, 192 Cal. App.3d 1022, 237 Cal. Rptr. 764 (1987).

120. See infra text accompanying notes 135-36.

121. See supra text accompanying notes $104-113$ and cases cited supra notes $111,114,115$.

122. See sources cited supra note 109. But see Blumberg, supra note 44, at $\$$ 23.02[3][d] (when one spouse is awarded entire pension on divorce, it is not problematic to consider the pension as income for determining alimony), 23.05[2][d] (not problematic to include income-producing asset, awarded to one spouse on divorce, as income for determining alimony), 23.08[8] (double counting is only problematic "when distribution is postponed until . . . an account receivable is collected or pension benefits are received"). 
a support claim by one spouse against the other. ${ }^{123}$ The issues are different. One might analogize to taxes. The same income may be subject to payroll taxes, to corporate and personal income taxes, and even to estate or gift taxes. The purpose of each tax is different, and they may be levied cumulatively on the same income.

The second justification is that double-dipping is ubiquitous in divorce-related property distribution and support awards. The value of any asset is its capacity to produce future income. ${ }^{124}$ In determining spousal support claims and obligations, all income from any source is credited to the support obligor or support obligee. ${ }^{125}$ When the wife is awarded a bank account and the family home, and the husband is awarded his professional goodwill, we should expect that the income from all assets will be available for the support calculus. The wife cannot shelter her income from the home (imputed rent) or her interest from the bank account on the theory that they were awarded to her in the distribution and hence their income should be excluded from the support analysis. That spouses, at least nominally, cannot be required to liquidate assets for support ${ }^{126}$ should not affect this analysis. Neither spouse is required to liquidate an asset within the meaning of this rule. That some goodwill may be realized only as future income because the goodwill is nontransferable or the spouse who possesses transferable goodwill has (wisely) elected to retain the business, should not affect our analysis. The capacity to make liquid a stream of future income has no logical bearing on whether that stream of income, when

123. See, e.g., Riley v. Riley, 571 A.2d 1261, 1264 (Md. Ct. Spec. App. 1990).

This justification is doctrinally more powerful in jurisdictions that sharply distinguish between property distribution and support claims. In California, for example, the division of community property at divorce executes the spouses' equal ownership rights in that property. Support entitlements, in contrast, are need-based. Yet in common law equitable distribution states, particularly the majority that do not have presumptive 50-50 distribution of marital property, there may be substantial nominal overlap between property and support because need-based criteria may be used in both determinations. (I say "nominal" because one scholar has found that most common law state courts have emphasized contribution to the exclusion of need in property distribution. Suzanne Reynolds, The Relationship of Property Division and Alimony: The Division of Property to Address Need, 56 FORDHAM L. REV. 827, 857 (1988).)

124. It is no answer to say, as one court did, in rejecting a husband's double-dipping argument:

[Husband-appellant] contends that the trial court gave appellee a double award by giving her both a portion of appellant's future earnings and a portion of the professional corporation's goodwill value. This argument is incorrect. As stated earlier, the capitalization of excess earnings method used to value goodwill examines appellant's past earnings, not his future earnings. Thus, there was no double recovery here, and no error by the trial court.

Clark v. Clark, 782 S.W.2d 56, 62 (Ky. Ct. App. 1990). The past earnings were used to value the future stream of earnings. See supra text accompanying notes 70-74. See also Fraase v. Fraase, 315 N.W.2d 271, 275 (N.D. 1982) (since court did not consider the future income capacity of the law firm when dividing the marital property, it was not improper to consider the future income in determining child support).

125. See, e.g., Riley, 571 A.2d at 1265; Lang v. Lang, 425 N.W.2d 800, 802 (Mich. Ct. App. 1988); Innes v. Innes, 542 A.2d 39, 41 (N.J. Super. Ct. App. Div. 1988); Kahn v. Kahn, 536 N.E.2d 678, 681-82 (Ohio Ct. App. 1987); Baumgartner v. Baumgartner, 770 P.2d 965, 966 (Or. Ct. App. 1989).

126. See, e.g., Ellsworth v. Ellsworth, 637 P.2d 564, 566 (N.M. 1981). This seems a "rule" followed more in the breach than the observance. Every time a spouse is denied adequate support, she is implicitly required to liquidate assets awarded to her in the property division. 
realized, should be deemed available for support. This line of analysis persuades me that double-dipping is nonproblematic.

A third justification is offered by David Dichener, a Los Angeles accountant. ${ }^{127} \mathrm{He}$ points out that, as a practical matter, the capitalization rates we apply to excess earnings, twenty to one hundred percent, are unavailable to the spouse who receives a compensating award in cash or other property. She will therefore not experience an economic equivalent to the stream of excess earnings enjoyed by her former spouse. She is not being paid twice (at least not fully) because of the spread between the capitalization rates applied at divorce and the rate of return she is able to secure in the market. Similarly, the business or professional spouse has not, as it turns out, paid fully because his future earnings were heavily discounted for risks that did not in fact materialize. ${ }^{128}$ (If they did materialize and he now has no excess earnings attributable to goodwill, he should not be making a double-dipping claim.) This line of analysis brings us almost full circle to the initial argument that the present value of goodwill, the heavily discounted, risk-laden opportunity to earn excess earnings, is conceptually distinct from those excess earnings, when and if they are in fact realized, and hence there is no double-dipping at all. ${ }^{129}$

\section{Assuming Double-Dipping is Problematic, How Should It Be Handled?} Although I am persuaded that double-dipping is acceptable, I will assume for the purpose of this section that double-dipping is a problem in search of a cure, and I will explore the various alternatives.

a. Not recognizing goodwill as an asset in property distribution or increasing the capitalization rate applied to excess earnings. Courts in a few jurisdictions have declined entirely to recognize goodwill as distributable marital property on the ground that future earnings may be tapped for spousal support. ${ }^{130}$ Other courts have refused to recognize goodwill as distributable property specifically in individual cases where spousal support is contemplated. ${ }^{131}$ Yet others courts apply unwarrantedly high capitalization rates to minimize the perceived unfairness of double-dipping. ${ }^{132}$ These responses are inappropriate methods of avoiding double-dipping. Spouses who receive little or no support may be unfairly shortchanged in the property division. Even when substantial support is contemplated, entitlements may be cut short by a variety of circumstances, including remarriage and changed economic circumstances.

127. David Dichener, Valuing Goodwill in a Professional Practice: Comments from a C.P.A., 6 CAL. FAM. L. MONTHLY 89, 94-95 (1989).

128. See similar discussion in Marriage of White, 192 Cal. App. 3d 1022, 1030, 237 Cal. Rptr. 764, 769 (1987).

129. See supra text accompanying note 119.

130. See cases cited supra in note 118.

131. See, e.g., Marriage of Hogeland, 448 N.W.2d 678, 681 (Iowa Ct. App. 1989) (since court considered goodwill in determining the amount of spousal support, the court should not have considered goodwill as an asset for property division).

132. See supra note 106. 
b. Treating as available for spousal support only the "reasonable compensation" figure used in the excess-earnings formula. The only argument in favor of using the "reasonable compensation" figure from the excess-earnings formula ${ }^{133}$ is ease of application. Economically it is incorrect. It freezes the support obligor's separate property earnings at the time of valuation. The professional's postvaluation earnings, if examined, may reflect returns on separate property postdivorce goodwill and inflationary and real increases in the value of the earner's labor, that is, in his human capital. These postdivorce separate property earnings should be treated as available for support, but they would be improperly excluded by this formulation.

c. Making the capitalized present value of the goodwill support-immune. Under this formulation, which is, among the alternatives, relatively generous to the supported spouse, the support obligor may, according to some schedule,$^{134}$ annually recover his basis, that is, the capitalized present value of the goodwill, immune from the support claims of the support obligee. If, for example, goodwill were valued at $\$ 100,000$ at divorce, in each of five successive years, the supporting spouse could shelter $\$ 20,000$ of current earnings from his former wife's support claims. ${ }^{135}$ Alternatively and even more favorably to the wife, only the wife's share of the goodwill, that is, the portion that the husband "purchased" from his wife at the divorce distribution, should be immune from her support claims.

Both formulations suffer from the defect of confusing present value with excess earnings when received, thus ignoring the time value of money. The present value of retaining $\$ 20,000$ a year for five years is not $\$ 100,000$, as this formula suggests. Nevertheless, this approach has a familiar feel. It resembles tax depreciation of an asset or basis recovery upon sale, both of which also do not consider the time value of money. The second variation poses an additional

133. See supra text accompanying notes $68-80$.

134. The schedule proposed may be derived from the "multiple," the inverse of the capitalization rate. One California participant recommended, for example, that excess earnings not be considered for spousal support during the "multiplier period." The term "multiplier period" illustrates the pitfalls of using the term "multiple." There is no such thing as a multiplier period. The multiple is simply the inverse of the capitalization rate. The multiple does not define the life of the asset. A multiple of five does not mean that the asset has a five-year life or that its present value will be recovered within five years.

Misunderstanding the "multiple" as a term of years, rather than simply the inverse of the capitalization rate, may be based on the notion of a payback period, with which some prospective purchasers set an upper limit on purchase price in terms of the number of years that it will take for future net receipts to equal the initial cash outlay for the purchase price. They speak, for example, about a four or five year recovery period. There is no valuation rationale for this practice other than recognition of cash flow constraints and the generation, for investment purposes, of cash flow predictions. PRATT, supra note 12, at 130-31. As a valuation technique, it would seem to have little or no relevance to divorced-related valuation of owner-retained businesses and practices.

135. See Pelot v. Pelot, 342 N.W.2d 64, 66 (Wis. Ct. App. 1983) (excluding pension benefits from income for maintenance purposes until the total benefits received equal the value of the pension awarded in the property division); accord Kruschel v. Kruschel, 419 N.W.2d 119, 123 (Minn. Ct. App. 1988). 
question. Is the vice of double-dipping that the professional or business spouse has already purchased his wife's portion of the marital goodwill? Or is it that he has been awarded the entire asset in the marital property distribution, and hence its entire value should be immune from support claims? I do not discern any clear answer to this question, perhaps because I cannot identify any principled basis for describing double-dipping as a problem.

d. Sheltering the support obligor's earnings for the estimated life of the marital goodwill to the extent that those earnings are attributable to marital goodwill. Subject to one critical defect discussed below, the most economically plausible and also the most potentially perverse rule would protect precisely that stream of earnings reduced to present value at divorce. If a surgeon has annual excess earnings of $\$ 100,000$, and he can persuade a court that his excess earnings are at such risk that they should be capitalized at $100 \%$, then under this rule he has purchased for $\$ 100,000$ an insurance policy immunizing $\$ 100,000$ of annual earnings into the foreseeable future from his ex-wife's support claims.

The difficulty with this formulation is that, given the high capitalization rates that are proposed by practitioners' attorneys and frequently accepted by courts, it is questionable whether the postdivorce earnings that the ex-husband seeks to shelter are in fact derived from the goodwill he earlier characterized as at great risk and of ephemeral life. It is only when we see much lower capitalization rates, for example, in the twenty to thirty-five percent range, that we can reasonably assume that what we are witnessing in the way of postdivorce earnings is indeed a return on marital goodwill. But even with such relatively low capitalization rates, the connection is not proven. At divorce, we have still assigned a capitalization rate that reflects a fairly high degree of risk. How do we know that the risks of nonrealization have not materialized and what we are now treating as support-exempt income is not really a return, for example, on postdivorce goodwill or on new human capital acquisition? Does this difficulty mean that the counter-intuitive argument with which I began this section is correct - that the risk-discounted present value of a future stream of earnings cannot be related, in the context of double-dipping, to future earnings actually realized?

e. Using wait-and-see payouts. Wait-and-see payouts may initially appear attractive as a method to avoid double-dipping. With marital property pensions, we often postpone distribution until pension benefits are realized. ${ }^{136}$ This results in both spouses sharing equally the risk of nonrealization. ${ }^{137}$ Moreover,

136. See, e.g., Marriage of Brown, 15 Cal. 3d 838, 544 P.2d 561, 567, 126 Cal. Rptr. 633 (1976); Robert C.S. v. Barbara J.S., 434 A.2d 383, 388 (Del. 1981); Jolis v. Jolis, 111 Misc.2d 965, 982 (N.Y. Sup. Ct. 1981), affd, 470 N.Y.S.2d 584 (N.Y. App. Div. 1983).

137. Marriage of Brown, 15 Cal. 3d at 848, 544 P.2d at 567, 126 Cal. Rptr. at 639 . Yet query whether equal risk-sharing is appropriate with unvested pensions (where the pensioned spouse may quit and lose all rights) or vested pensions (where the worker has more control over his longevity than does his former spouse). 
for support purposes, the support obligor's income will not include the portion of monthly pension benefits received by his former spouse, and the support obligee's income will include her share of the monthly benefits. At first blush this possibility seems attractive, but on closer examination wait-and-see distribution, as applied to goodwill, is both conceptually problematic and moreover is likely to be perceived by support obligors as an insignificant cosmetic adjustment rather than a cure for double-dipping.

A wait-and-see remedy is conceptually problematic at the deepest level because if, for example, we identify $\$ 50,000$ of excess earnings at divorce and use a wait-and-see remedy, we would then treat $\$ 50,000$ of business or practice excess earnings, inflation-adjusted and tax-reduced, as divisible property into the indefinite future. Yet we really have no idea whether these earnings are in fact attributable to marital goodwill. In other words, we have no way of knowing whether the substantial risks we purport to identify in our twenty to one hundred percent capitalization rates have in fact materialized, and therefore postdivorce excess earnings are attributable to postdivorce separate property imputs. Moreover, we have no way, short of elaborate proof highly subject to manipulation by the practitioner spouse, to know whether and when marital goodwill is exhausted or substantially dissipated. ${ }^{138}$ Thus, the accounting difficulties of goodwill prediction and tracing, which are adequately treated in present valuation by the application of risk-discounted capitalization rates, ${ }^{139}$ assume overwhelming proportions when we contemplate a wait-and-see approach to returns on marital goodwill after divorce. ${ }^{140}$

We might take the position, as most "wait and see" proponents seem to, that for a given number of postdivorce years, any excess earnings up to the amount identified as "excess" at divorce would be treated as a return on marital property goodwill. Thus, for example, if Dr. Spouse had $\$ 50,000$ excess earnings at divorce and, after divorce, continued to net at least $\$ 50,000$ excess earnings annually, then for some number of years the $\$ 50,000$, inflation-adjusted and income tax-reduced, would be treated as a return on marital goodwill to be shared by Dr. Spouse and his former mate.

Former mates would tend to like such resolutions because they are currently unable to produce similar streams of future income with present value awards of

138. It is no answer to say that we will use the number of years implied by the multiple because the multiple, the inverse of the capitalization rate, implies nothing about the life expectancy of the goodwill. For discussion of this frequent confusion, see supra text accompanying notes 21-23 and note 134 .

Pensions, in contrast, are much more manageable. Yet even with pensions, when we use the time rule in conjunction with deferred distribution of benefits ultimately received, we have muddied the distinction between community and separate labor imputs. See GRACE GANZ BLUMBERG, COMMUNITY PROPERTY IN CALIFORNIA 390-97 (2d ed. 1993).

139. See supra text accompanying notes 14-26. Errors of prediction about the relatively remote future are made insignificant by discounting to present value at relatively high capitalization rates.

140. In terms of the accounting literature, present valuation involves us in manageable sales valuation issues. Wait-and-see would embroil us in the bookkeeping methodology and amortization difficulties that accounting theory has never adequately resolved because they are intractable. See CATLETT \& OLSON, supra note 9; HUGHES, supra note 11. 
goodwill, that is, they are generally unable to invest their present value awards at the capitalization rates we apply to reduce future goodwill income to present value. ${ }^{141}$ But this approach would substantially increase the cost of goodwill buy-outs to the person the double-dipping solutions are intended to help: the business or professional spouse. This cost increase occurs because the business or professional spouse loses the advantage of the high capitalization rates used to reduce goodwill to present value. So long as he continues to generate excess earnings in the amount of his predivorce excess earnings, he pays undiscounted value for the marital goodwill.

Working through the wait-and-see remedy does potentially illuminate one double-dipping issue: whether the objectionable double-dip involves the wife's portion or all of the marital property goodwill. The wait-and-see avoidance maneuver protects the practitioner from paying for his spouse's interest twice; the amount he pays to settle her marital property claim is not tapped again for spousal support. His portion of the excess earnings is, however, available for spousal support. Assume, for example, a wait-and-see equal division of the husband-practitioner's $\$ 50,000$ excess earnings for ten years. The husband pays the wife $\$ 25,000$, inflation-adjusted and tax-reduced, for ten years as her waitand-see distribution. There is no double-dipping because only his remaining income is available for support. Thus the wait-and-see resolution shelters only half the excess earnings attributable to marital goodwill. ${ }^{142}$

There are practical, as well as conceptual, difficulties with a wait-and-see payout. The practitioner may seek to conceal future excess earnings, and his former spouse may thus be required to spend a substantial portion of her share on attorneys' and accountants' fees. In contrast with current practice, goodwill awards will no longer provide a convenient property counterweight at divorce, and thus it will generally be more difficult to award the family home to the nonpractitioner custodial parent.

Despite its conceptual and practical difficulties, a wait-and-see resolution has a number of positive features. It obviates concerns about double-dipping and taxation because double-dipping is avoided and taxation is taken into account. It allays anxiety the practitioner may experience in present valuation, where he is required to compensate his wife for her interest in the present value of as-yetunrealized earnings. A wait-and-see order, with its "when and if earned" proviso assures him that he will not have to pay if he does not in fact realize future excess earnings. It avoids, as well, his wife's conviction that she is being shortchanged by capitalization rates that seem, to her, greatly to overestimate the risk in her husband's business or practice, rates that she generally cannot obtain in any investment available to her.

141. Dichener, supra note 127 .

142. This analysis has greater force in jurisdictions having strong notions that spouses equally own marital property, or that they equally contribute to the acquisition of marital property, or that they are equally entitled to distribution of the marital property at divorce. It has less force in the absence of such principles. 
In wait-and-see resolutions, the critical issue will be the life of the excess earnings attributable to marital goodwill. There will need to be considerable discussion and debate about the nature and life of small business and professional goodwill. This article has argued that this discussion is unnecessary when we look to market capitalization rates because market assumptions about life are embodied in those rates. If we abandon capitalization, we cannot look to those rates for guidance because they embody both risk and life, and we have no market-informed way of disaggregating the two factors.

ISSUES INCIDENT TO THE TRANSFER OF GOODWILL

\section{A. Covenants Not to Compete}

Covenants not to compete often accompany market transfers of marital goodwill. Such covenants may appear problematic because they are promises not to perform in the future services that would generate, at least in part, separate property income. Thus, one might reason, proceeds from a covenant not to compete contemplating nonperformance of postdivorce services should be treated as the seller's separate property. Yet the purpose of the covenant not to compete is to refrain from interfering with the transfer of marital goodwill. If the seller continues to practice or trade in the same locale, his clientele would not be transferred to the buyer. The seller would retain the very goodwill he is purporting to sell to the buyer. Under the covenant, the seller is free to practice elsewhere and to realize the value of his postdivorce labor. The true economic subject of the covenant not to compete is the marital goodwill, not the husband's postdivorce labor. Thus, the existence of a covenant not to compete, incident to actual or hypothetical sale of marital property goodwill, should not give us pause. The value of an actual or hypothetical covenant should not be used to diminish the otherwise-ascertained value of the marital goodwill. In the event that marital goodwill has actually been sold in the market, any extra premium for a covenant not to compete should be treated equally as marital property.

Most divorce distribution cases present hypothetical, rather than actual, sales of goodwill because most divorcing practitioners retain their businesses or practices. Thus, most reported cases present a claim by the practitioner spouse that the value of the marital goodwill, whether ascertained by comparable market sales or by excess-earnings capitalization, should be diminished by the value of the covenant not to compete that would be required of the practitioner spouse were he to sell the business or practice. Courts have usually rejected such claims, ${ }^{143}$ although sometimes for an excessively narrow reason. They some-

143. See, e.g., Marriage of Czapar, 232 Cal. App. 3d 1308, 285 Cal. Rptr. 479, 481 (1991); Mitchell v. Mitchell, 719 P.2d 432, 438-39 (N.M. Ct. App. 1986); Marriage of Sommerfield, 454 N.W.2d 55, 60-61 (Wis. Ct. App. 1990). Contra Rathmell v. Morrison, 732 S.W.2d 6, 18-19 (Tex. App.-Houston [14th Dist.] 1987, no writ). 
times respond that it would be unduly speculative to value a hypothetical covenant: The practitioner may never transfer his business and, even if he does, the covenant may be costless to him, for example, when the transfer occurs at his retirement. ${ }^{144}$

This line of reasoning may be understood to suggest that such covenants do require attention when they are incident to actual sales of marital goodwill. Other courts have understood that the true rationale is much broader: The seller's covenant not to compete is simply a means of insuring the transfer of marital goodwill to a market purchaser; hence such covenants should properly be understood as an aspect of marital goodwill. ${ }^{145}$ Their hypothetical value should not be used to diminish the value of marital goodwill. Actual premiums paid for such covenants should be deemed payment for marital goodwill.

\section{B. Promises to Continue in the Practice or Business}

In order to effectuate the transfer of goodwill, sellers sometimes promise to remain in the business or practice to smooth the transition for the purchaser.

144. Compare Lucas v. Lucas, 621 P.2d 500 (N.M. 1980) and Mitchell v. Mitchell, 719 P.2d 432 (N.M. Ct. App. 1986). In Lucas, a divorcing mortician sold his community property stock in his mortuary corporation for a price found fair and reasonable. As part of the stock sale, he covenanted with the buyer not to practice his profession in the county for ten years following the stock sale. Under this collateral agreement, the divorcing husband was to receive $\$ 10,000$ a year for ten years. The trial court treated the $\$ 100,000$ as additional community property compensation for the sale of the stock. The supreme court disagreed because of the trial court's finding that the price set for the stock alone was fair and reasonable, and thus held that the $\$ 100,000$ must be the husband's separate property: “Under these particular facts we cannot see how we can equate the covenant not to compete with good will." 621 P.2d at 502. The New Mexico Supreme Court was easily confused. The stock price was "fair and reasonable" without a covenant not to compete. The covenant not to compete added value to the stock. The total value of the transferred goodwill is reflected in the sum of the stock price and the covenant price.

Lucas presents the relatively rare case of an actual sale. In Mitchell, an accountant's goodwill in an ongoing CPA practice was valued by earnings capitalization. He argued that, as per Lucas, the intangible asset characterized as community property goodwill should instead have been characterized as his separate property covenant not to compete. The court rejected this argument, distinguishing Lucas on the ground that Lucas involved an actual sale; hypothetical covenants not to compete, in contrast, should not be used to diminish the capitalized value of community goodwill. 719 P.2d at 438 . The analysis of Mitchell, however, exposes the fallacy of Lucas: "When a buyer insists on a noncompetition agreement, he or she is seeking to preserve the goodwill .... In cases such as this one, a hypothetical covenant not to compete should not be valued on divorce but should be viewed as a possible means to protect the value of the business' goodwill." Id. at 438-39.

Following Mitchell's narrow holding, Marriage of Czapar, 232 Cal. App. 3d 1308, 285 Cal. Rptr. 479 (1991), held that a hypothetical covenant not to compete, which the husband would be required to give were he to sell his business, should be ignored in the valuation of his ongoing business. Nevertheless, the California appellate court accepted, in dictum, the proposition that a covenant not to compete actually negotiated as part of the sale of the property would be the manager-spouse's separate property. Id. at 481. See also Marriage of Lotz, 120 Cal. App. 3d 379, 174 Cal. Rptr. 618, 620 (1981) (using excess earnings method of valuation and finding that covenant not to compete would be required in an actual sale, court rejected husband's claim that hypothetical covenant should be taken into account in valuation).

145. Carr v. Carr, 701 P.2d 304, 309 (Idaho Ct. App. 1985); McGehee v. McGehee, 543 So.2d 1126, 1128 (La. Ct. App. 1989); Lord v. Lord, 454 A.2d 830, 834 (Me. 1983); Marriage of Sommerfield, 454 N.W.2d at 60-61. See also Jewel Box Stores Corp. v. Morrow, 158 S.E.2d 840, 845 (N.C. 1968) (the execution of covenant not to compete, in connection with the sale of business, is essentially sale of business goodwill). 
One commentator ${ }^{146}$ has suggested that sales prices from such sales overstate the value of the practice for nonsale marital property distribution purposes because they include a premium for the seller's continuing presence. This conclusion may be correct in jurisdictions that place a market lid on goodwill valuation, but it is incorrect in the majority of jurisdictions that seek to value all marital goodwill, both transferable and nontransferable.

The continuing presence of the seller is necessary to execute an effective transfer of whatever portion of the seller's goodwill will survive a transfer under optimal conditions, that is, with the seller's transitional services. These transitional services are unneeded when no transfer is contemplated, as at divorce. The question we should be asking at divorce is: What would an out-oftown practitioner of similar training and experience pay to acquire successfully all of Dr. Spouse's goodwill? This unrealizable opportunity is clearly more valuable than the alternative real-life possibility of buying Dr. Spouse's practice and having Dr. Spouse stay on for a few months to smooth the transition. That, in the second situation, Dr. Spouse will stay on for a few months does not make the second opportunity more valuable than the first. On the contrary, the second situation is clearly less valuable. That Dr. Spouse has to stay on is, moreover, some indication of the difficulty of goodwill transfer, which should alert us to the possibility that the market price may substantially understate the value of the goodwill in Dr. Spouse's hands.

\section{VI \\ EXPANDING THE CONCEPT OF PROFESSIONAL AND COMMERCIAL GOODWILL TO RELATED FORMS OF GOODWILL AND TO ENHANCED MARITAL EARNINGS IN GENERAL}

\section{A. Introduction}

In the California goodwill colloquia, ${ }^{147}$ many participants expressed their belief that California should extend some variety of excess-earnings methodology to celebrity goodwill and employee, or executive, goodwill. Their conviction is based upon the view that celebrity goodwill and executive goodwill are conceptually akin to the reputation and custom components of traditional commercial and professional goodwill.

\section{B. Various Meanings of "Excess Earnings"}

One way to broach the issues of similarity and difference between the traditional and emergent concepts is to compare the various possible definitions of "excess earnings."

146. Udinsky, supra note 16 , at 37.

147. See supra text accompanying notes $4-5$. 
1. Traditional Excess Earnings. The traditional formulation ${ }^{148}$ defines excess earnings as earnings above and beyond all identifiable imputs from labor, tangible assets, and separable intangible assets. Labor is defined as the market labor value of the services of a person with the business or professional spouse's education, training, experience, and ability. Conceptually, at least at a theoretical level, this is a sound and easily defended construct. Excess earnings are, or should be, earnings above and beyond what this divorcing spouse would be earning were he to sell his services to an employer in the labor market. These excess earnings are attributed to a constellation of intangible assets that the spouse has developed in the context of a particular business or practice.

2. The Average-Earnings Variation. The average-earnings variation compares the professional spouse's earnings to those that an average professional earns. ${ }^{149}$ This formula does not provide a residual measure of goodwill; instead it may be understood variously to show above-average earnings or above-average goodwill. Conceptually, this formula does not embody any coherent theory of marital property recognition or valuation. It is not clear why the marital community should have any claim, as a property right, to some present value of a portion of a spouse's postdivorce earnings simply because they are "above average." The lack of conceptual basis for this approach may explain some of the hostility to current treatment of goodwill. It is important, however, to note and understand this variation because existing use of the average-earnings variation for measurement of professional goodwill may explain receptivity to similar measures of celebrity and executive goodwill. ${ }^{150}$

3. The Piscopo Measure of Celebrity Goodwill. Piscopo ${ }^{151}$ measures celebrity goodwill by a formula lying somewhere between the traditional commercial/professional business measure and the average-earnings variation. It measures celebrity goodwill as celebrity earnings (from freelance contracts) less reasonable compensation for the work. Piscopo tries to extract the spouse's labor value by reference to some notion of reasonable compensation. Excess compensation is attributed to goodwill or reputation, which is marital property insofar as the reputation or goodwill was accumulated during marriage.

Piscopo methodology looks to some measure of the average earnings of employed entertainers, ${ }^{152}$ thus posing problems similar to those of the averageearnings variation. It asks: Are we just identifying above-average earnings or

148. See supra text accompanying notes $67-70$.

149. See supra text accompanying notes 77-80.

150. I do not endorse this approach. I discuss it for its explanatory value.

151. Piscopo v. Piscopo, 555 A.2d 1190, 1191-92 (N.J. Super. Ct. Ch. Div. 1988), aff'd, 557 A.2d 1040 (N.J. Super. Ct. App. Div.), cert. denied, 564 A.2d 875 (N.J. 1989). Cf. Elkus v. Elkus, 572 N.Y.S.2d 901, 904 (1st Dept. 1991), appeal dismissed, 588 N.E.2d 99 (N.Y. 1992) (using increased earnings during marriage as the measure of opera singer Frederica von Stade's marital celebrity goodwill). Elkus is discussed infra text accompanying notes 155-62.

152. 555 A.2d at 1193 . 
above-average goodwill? ${ }^{153}$ The formula gives us no benchmark for determining what Joseph Piscopo would be earning as an entertainer without his maritally developed reputation, or goodwill. Yet if our fairly confident answer to that question is "very little," we should not hesitate to use the New Jersey court's formulation; its only vice is that it understates the value of his goodwill.

Because reputation is often a sine qua non for any significant earning by an entertainer, the defect of the average-earnings method, when applied to commercial businesses and professional practices, may be of little consequence when used for entertainers. To the extent we are persuaded that any entertainer's reputation is of the essence in producing his earnings, and that acquisition of that reputation may entail serious opportunity costs for the marital community, use of the Piscopo formula would seem justified for entertainers, even though the use of a similar formula-the average-earnings variation-is highly questionable for commercial businesses and professional practices, given the different economic context (professional and commercial workers without goodwill may nevertheless be well-rewarded in salaried labor) and the existence of a conceptually sound alternative.

4. Above-Normal Salary for Executive Goodwill. Proposals suggesting that we recognize executive goodwill as a marital asset usually suggest comparing a spouse's above-normal salary with normal or average salaries for executive workers. The difference is "executive goodwill." The conceptual difficulty with such a formulation is that it does not address the possibility that the spouse's labor may be superior. Since the executive spouse and the "average" executives are competing in the same labor market, it is plausible to assume that the market values their labor differently. This difficulty does not arise, at least not with equal force, ${ }^{154}$ in traditional commercial business and professional goodwill capitalization, where we attempt to ascertain what the subject could obtain in the labor market with his education, skill, and experience. The excess earnings we capitalize are over and above the salary he could command in the labor market and are directly attributable to a constellation of intangible values regularly measured by accountants for a variety of business purposes.

5. Noninflationary Increases in Earning Power During Marriage. Moving even further afield but onto economically sounder ground, we might compare the individual earner on the eve of marriage and at divorce, treating all ${ }^{155}$ noninflationary increase as a marital asset. This formulation compares the

153. Presumably, all employed entertainers possess some goodwill.

154. But see James Friedman, who argues that the professional entrepreneur's labor is not comparable to the labor of the identically qualified salaried professional because the entrepreneur assumes the risk of business failure. James T. Friedman, Professional Practice Goodwill: An Abused Value Concept, 2 J. AM. ACAD. MATRIM. L. 23, 25-28 (1986). Yet the risk faced by the entrepreneurial professional is, over the long run, largely reflected in excess earnings, not in the labor value imputed to him in the excess-earnings formulation. If the entrepreneurial professional discovers that he could earn more as a salaried worker, he can always abandon his practice and take salaried employment.

155. Or we might apportion the increase between arguably separate and marital sources. 
spouse with himself, is easy to administer, and is not hypothetical. In a broad sense it is also consistent with marital property principles in that it allocates to the marriage all gains attributable to marital labor. Yet this formulation would capture all human capital gains, a principle that most states have explicitly rejected with respect to the acquisition of professional education and licenses during marriage. ${ }^{156}$

New York, one of the two states recognizing professional education as marital property, ${ }^{157}$ seems to have arrived at this position within six years of first holding that a medical degree and license are marital property. ${ }^{158}$ In Elkus v. Elkus, ${ }^{159}$ the Appellate Division held that the increase in value during marriage of a divorcing spouse's career status is marital property subject to equitable distribution. Although nominally dealing with the "celebrity goodwill" of the opera singer Frederica von Stade, the court's rationale and measurement technique embrace all gains in earning capacity during marriage. The court focused on "enhanced skills," 160 measuring the marital interest in the singer's annual earnings by subtracting her annual premarital earnings from her greatly increased annual earnings at the end of marriage. ${ }^{161}$ The court emphasized the husband's contribution to his wife's career as a voice coach and as a caretaker of their children, repeating the language of $O$ 'Brien concerning "direct or indirect contributions of the non-title-holding spouse, including financial contributions and nonfinancial contributions made by caring for the home and family." 162

6. The Excess of One Spouse's Income over the Other's. We might think about excess earnings in terms of postdivorce income inequality between the former spouses. In this formulation, we would compare the postdivorce income of both spouses and award the lower-income spouse some percentage, fifty percent or less, of the difference. This formulation is not based upon explicit principles of marital property law in the sense that it does not seek to tie the higher earner's excess income to any marital accomplishment or gain. It does not refer to the usual justification that marital labor enabled postdivorce gains in earnings, and hence it does not require that the higher-earner's income have increased during marriage. This formulation simply compares the incomes of the spouses and makes some attempt to equalize them.

Although this formulation exceeds any current legal understanding of the scope of marital property distribution at divorce, it is nevertheless responsive to many of the social factors that argue in favor of marital property systems, in favor of expansive definitions of marital property generally and, specifically, in favor of expansive definitions of maritally acquired goodwill. Such factors

156. See supra note 77 .

157. Id.

158. O'Brien v. O'Brien, 489 N.E.2d 712, 717 (N.Y. 1985).

159. 572 N.Y.S.2d 901, 904 (1st Dept. 1991), appeal dismissed, 588 N.E.2d 99 (N.Y. 1992).

160. Id.

161. Id.

162. Id. at 903 (citations omitted). 
include pervasive sex-based earned-income inequality, which is manifest within individual families as well as across the labor market, ${ }^{163}$ the labor market opportunity costs experienced by mothers during marriage and after divorce, ${ }^{164}$ and the extent to which sex-based socialization controls the occupations we "choose" and the social roles we occupy.

7. Conclusion. In this section, I have compiled and contrasted various definitions of the ambiguous term "excess earnings" in order to identify and clarify the various meanings and difficulties that each definition presents. I do not mean to foreclose the use of any particular definition for any special purpose. Indeed, as I have suggested above, a definition that is misleading and unjustifiable for professional practices may make sense for celebrity goodwill, at least if the claim for recognition seems sufficiently compelling and there is no alternative valuation measure. The next sections will begin, not with "excess-earnings" formulations, but with descriptions of the assets sought to be valued.

\section{Executive Goodwill}

Insofar as the central notion of goodwill consists in winning confidence from patrons and securing immunity from competition, ${ }^{165}$ highly paid executives may benefit from the same competitive advantages enjoyed by business entrepreneurs and private professional practitioners. Just as the physician's capacity to create a relationship of trust with a patient insulates the physician against price competition, so the executive who is able to gain similar reputation and trust in his company or business community insulates himself against normal price competition in the labor market. Whether the executive possesses an ownership interest in the business entity is immaterial. The measure of the executive's goodwill is, at a minimum, the excess of his salary over the market level for the quality and amount of services rendered-at a minimum because highly paid executives as a group, in reaching the top of the pyramid, may be understood to have developed a certain immunity from labor market competition. Thus, wage comparisons with executives performing similar work may tend to show only "excess goodwill," rather than all goodwill. The potential for understating value is not, however, an argument against executive goodwill recognition and valuation.

\section{Entrepreneurial Employee Goodwill}

Some employees enjoy entrepreneurial compensation arrangements, yet they have no ownership interest in any business. Such employees include, for example, the commissioned salesman who has developed a valuable customer list,

163. E.g., VICTOR R. FUCHS, WOMEN'S QUEST FOR ECONOMIC EQUALITY 52 (1988) ("Not only do women earn less than men on average, but an equally large differential emerges in direct husband-wife comparisons of individual couples.").

164. Id. at 58-64.

165. See supra text accompanying notes 84-87. 
the experienced hairstylist who moves from salon to salon, taking his customers with him and receiving compensation or commissions commensurate with his entourage of customers, and the travel agent who moves, with his personal clients, from agency to agency, cutting ever-better deals for commission-splitting. These employees resemble professional practitioners in that their client relationships are based on personal trust and their customer lists may not be marketable or, if marketable, will be heavily discounted for customer loss during and after transfer.

Measurement of such goodwill does not seem particularly problematic. Markets exist for employees who are similarly trained and experienced, but have not developed personal customer lists. The difference between the entrepreneurial employee's earnings and the market rate for his labor may be characterized as excess earnings, or return on goodwill.

\section{E. Inchoate Employee Goodwill}

In the course of his employment, an employee may develop many business contacts that he later exploits when he develops his own business. Executives in the entertainment business often move, in mid-career, from salaried positions to freelance, consulting, or entrepreneurial activities, to which they bring goodwill in the form of reputation and client contacts established during their salaried employment. Not infrequently, these financially lucrative moves are coextensive with other life changes, such as divorce.

Recognition and valuation techniques already in use are available to measure the marital interest in such goodwill. The excess-earnings method can be used to measure the marital goodwill. Because only postdivorce earnings will be available for businesses begun around or at divorce, apportionment must be made between marital and postmarital goodwill. Tracing should not be difficult, however, when the claim is one of continuity of contacts and reputation.

\section{F. Celebrity Goodwill}

Commentators have identified two distinctly different aspects of celebrity goodwill. ${ }^{166}$ The first, the right of publicity, is relatively unproblematic and uncontroversial. The second, the capacity to generate above-average earnings, presents more difficulty.

1. The Right of Publicity. Celebrities often make money from endorsements or perfunctory guest appearances. These exploitations of celebrity fame generally entail no use of valuable talent and experience on the part of the celebrity. Compensation is clearly "excess" because it is incommensurate with ordinary compensation for the labor involved. In such cases compensation is intended not for the labor, but for the exploitation of the spouse's fame. To the

166. Stuart B. Walzer \& Jan C. Gabrielson, Celebrity Goodwill, 2 J. AM. ACAD. MATRIM. L. 35 (1986). 
extent that personality or celebrity status was developed during marriage, the profit from exploitation should be understood as marital property.

Because exploitation of personality is freighted with concerns about privacy and personal integrity, ${ }^{167}$ celebrities should not be required to exploit personality in order to avoid wasting a marital asset. Thus, distribution at divorce should be handled on a wait-and-see basis. The danger of income concealment seems slight because exploitation of the right of publicity should give adequate notice to the celebrity's former spouse.

2. Excess Celebrity Earnings. More troubling are claims with respect to primary postdivorce celebrity earnings, those the celebrity is paid for the activity for which he enjoys fame. Here the marital community asserts that some portion of such postdivorce earnings are "excess earnings," or a return on marital goodwill.

Celebrities are lottery winners, often talented lottery winners, but lottery winners nevertheless. They are usually found in fields with many low earners. It is the possibility of becoming a celebrity that leads to overcrowding in these fields. For every musical virtuoso, there are hundreds of orchestra players and hundreds more unemployed and underemployed musicians. Thus, the lion's share of a celebrity's earnings may be attributable to the earner's celebrity status. ${ }^{168}$ Yet to the extent that celebrity status was developed during marriage, the claim of the marital community is often compelling because the community was deprived or economically depleted by the pursuit of a highly competitive career in which most competitors fare poorly until, if ever, they obtain celebrity status.

Celebrity status also sharply poses the problem of uniqueness. ${ }^{169}$ This problem is rare in the professions, where most of us are professionally replaceable despite our preference for thinking otherwise. Some holders of celebrity status may indeed be unique. In sports, opera, comedy, film, and theater, we can all think of more than a few examples. We are reluctant to use comparable labor data to value the services of Wayne Gretzky, Whoopie Goldberg, Robin Williams, or Glenda Jackson. According to our tastes, Luciano Pavarotti may have goodwill, but Placido Domingo has an incomparable voice. Even for celebrities who are merely talented, as opposed to unique, it seems questionable to use "average" compensation figures for those of similar training and experience. Moreover, similar experience suggests that many "average"

167. See REPPY \& SAMUEL, supra note 54, at 13-9.

168. This contrasts sharply with, for example, professional practitioners, who receive a hefty imputed return to postdivorce separate property labor and a generally smaller residue to goodwill.

169. Piscopo and Elkus rejected the argument that celebrity goodwill is distinguishable from professional goodwill because celebrity goodwill may entail great talent. Both courts observed that those who succeed in any specialized discipline have particular talents. Piscopo v. Piscopo, 555 A.2d 1190, 1192 (N.J. Super. Ct. Ch. Div. 1988), aff'd, 557 A.2d 1040 (N.J. Super. Ct. App. Div.), cert. denied, 564 A.2d 875 (N.J. 1989); Elkus v. Elkus, 572 N.Y.S.2d 901, 904 (1st Dept. 1991), appeal dismissed, 588 N.E.2d 99 (N.Y. 1992). 
workers themselves must possess some goodwill in the form of reputation. If we were, for example, to ask film producers what they would offer Tom Cruise to star in a film if he were unknown, they might answer "nothing at all," because what they are looking for in a lead is "heat," that is, public desire to see the celebrity perform, which is measured by box office returns from previous pictures. ${ }^{170}$ On the other hand, sports teams have a good deal of experience in hiring highly talented, not-yet-famous players.

This discussion suggests that although there may be no readily available universal technique for valuing celebrity goodwill, each celebrity medium may present its own appropriate measuring standards. To the extent, for example, that an actor's postdivorce "heat" is generated by the box-office receipts of films made during marriage, a strong case is made for marital property recognition of some portion of the value of his postdivorce film contracts. A particularized inquiry into the basis for the postdivorce contract prices with those who negotiated the contracts, or with industry experts, might generate the data necessary to allocate between marital property heat and postdivorce labor. Pricing mechanisms for concert musicians show similar patterns. In other areas, celebrity pricing mechanisms may suggest different methodologies for allocating between marital goodwill and postdivorce labor.

\section{G. Hitting the Wall: Current Earnings are Often, to Some Extent, Enhanced by Prior Accomplishment}

In discussing a film star's "heat," I noted the extent to which a star's postdivorce contracts may be priced in terms of the gross receipts of films he made during marriage. When connections between marital labor and postdivorce income are this obvious, many respond positively to marital claims for recognition and valuation. Yet most wage levels for personal labor and services are set with reference to past performance. My current salary level as a UCLA professor is the result of twenty years of academic labor during marriage. More narrowly, merit increases based upon publication become a permanent increment to my annual salary. To the extent that the publications were produced and the ensuing merit increases were awarded during marriage, there are clearly identifiable components of ongoing postdivorce salary that are attributable to marital effort. More generally, every time-and-grade promotion during marriage is traceable to marital labor. This analysis would tend to support a more generous excess-earnings formulation, one that would identify as marital property all noninflationary increase in earning power during marriage.

Is it possible, conceptually, to distinguish between celebrity goodwill and ordinary merit increments to salary? It might be argued that the merit increases that, for example, follow publication are intended to reflect real improvement in the quality of my labor, which improvement is caused or evidenced by publication. Similarly, regular time-and-grade promotions are intended to reflect

170. Walzer \& Gabrielson, supra note 166 , at 39. 
improvements in the quality of labor gained through teaching and research experience. Does this adequately distinguish celebrity "heat" or business and professional goodwill? ${ }^{171}$

\section{H. Conclusion}

This section of the article has compared traditional commercial and professional goodwill with emergent goodwill claims, such as employee and celebrity goodwill. It took two approaches. The first explored the different meanings that we might give to the term "excess earnings." The second approach started with particular claims that the marital community might make in the emergent areas. The first approach, although useful as an exercise in definition, did not open up the subject as well as did the second. Examination of the particular claims that the marital community might make in different areas tended to suggest measurement techniques. In looking at celebrity goodwill, for example, no one measurement device seemed suitable for all celebrities. Yet when thinking about film stars, motion-picture contract pricing practices suggested how their goodwill might be valued.

\section{VII}

\section{CONCLUSION}

This article has had three purposes: to describe current American marital property treatment of professional and commercial goodwill; to analyze contested areas of doctrine and practice; and to explore the doctrinal and conceptual frontiers of the subject. The first two tasks entailed, in many respects, selfcontained exercises in logic and legal analysis. In contrast, any conclusions about the desirability of extending goodwill beyond its current boundaries would require extended discussion of the legitimate purposes of marital property distribution, the extent to which marital property doctrine should be fashioned to produce fair outcomes at divorce, and the very content of fairness. Exploring fairness would require, for me, an elaborated consideration of the pervasive role of gender in the economic positions of the spouses at divorce. I have not undertaken any of these necessary tasks in this article and hence offer my exploration of the frontiers as simply that. I trace paths that may or may not be taken as we determine what we want to make of marital property. I neither endorse nor reject these possibilities, but welcome them as provocative opportunities to reflect upon our goals. But that reflection is the subject of another article.

171. See Marriage of Hall, 692 P.2d 175, 180, 182 (Wash. 1984) (en banc) (finding goodwill in a cardiologist's private practice but rejecting the possibility that his highly successful wife, a salaried medical school professor, might have cognizable goodwill). 